\title{
Review \\ Regulation Mechanism of ssDNA Aptamer in Nanozymes and Application of Nanozyme-Based Aptasensors in Food Safety
}

\author{
Lijun Wang ${ }^{1}{ }^{(}$, Hong Zhou ${ }^{1}$, Haixia Hu ${ }^{1}$, Qin Wang ${ }^{2, *(\mathbb{D}}$ and Xianggui Chen ${ }^{1, *}$ \\ 1 School of Food and Bioengineering, Xihua University, Chengdu 610039, China; \\ wanglijun@mail.xhu.edu.cn (L.W.); zhouhong19980510@163.com (H.Z.); \\ 212021083200011@stu.xhu.edu.cn (H.H.) \\ 2 Department of Nutrition and Food Science, University of Maryland, College Park, MD 20742, USA \\ * Correspondence: wangqin@umd.edu (Q.W.); chen_xianggui@mail.xhu.edu.cn (X.C.); Tel.: +1-301-405-8421 \\ (Q.W.); +86-028-8772-0550 (X.C.)
}

check for updates

Citation: Wang, L.; Zhou, H.; Hu, H.; Wang, Q.; Chen, X. Regulation Mechanism of ssDNA Aptamer in Nanozymes and Application of Nanozyme-Based Aptasensors in Food Safety. Foods 2022, 11, 544. https://doi.org/10.3390/ foods11040544

Academic Editor: Mark Mooney

Received: 23 December 2021

Accepted: 5 February 2022

Published: 14 February 2022

Publisher's Note: MDPI stays neutral with regard to jurisdictional claims in published maps and institutional affiliations.

Copyright: (C) 2022 by the authors. Licensee MDPI, Basel, Switzerland. This article is an open access article distributed under the terms and conditions of the Creative Commons Attribution (CC BY) license (https:// creativecommons.org/licenses/by/ $4.0 /$ )

\begin{abstract}
Food safety issues are a worldwide concern. Pathogens, toxins, pesticides, veterinary drugs, heavy metals, and illegal additives are frequently reported to contaminate food and pose a serious threat to human health. Conventional detection methods have difficulties fulfilling the requirements for food development in a modern society. Therefore, novel rapid detection methods are urgently needed for on-site and rapid screening of massive food samples. Due to the extraordinary properties of nanozymes and aptamers, biosensors composed of both of them provide considerable advantages in analytical performances, including sensitivity, specificity, repeatability, and accuracy. They are considered a promising complementary detection method on top of conventional ones for the rapid and accurate detection of food contaminants. In recent years, we have witnessed a flourishing of analytical strategies based on aptamers and nanozymes for the detection of food contaminants, especially novel detection models based on the regulation by single-stranded DNA (ssDNA) of nanozyme activity. However, the applications of nanozyme-based aptasensors in food safety are seldom reviewed. Thus, this paper aims to provide a comprehensive review on nanozyme-based aptasensors in food safety, which are arranged according to the different interaction modes of ssDNA and nanozymes: aptasensors based on nanozyme activity either inhibited or enhanced by ssDNA, nanozymes as signal tags, and other methods. Before introducing the nanozyme-based aptasensors, the regulation by ssDNA of nanozyme activity via diverse factors is discussed systematically for precisely tailoring nanozyme activity in biosensors. Furthermore, current challenges are emphasized, and future perspectives are discussed.
\end{abstract}

Keywords: nanozyme; ssDNA aptamer; regulation mechanism; biosensor; food safety

\section{Introduction}

Food safety has become a major global concern because of its impacts on public health as well as the international food trade. Pathogens, toxins, pesticides, veterinary drugs, heavy metals, and illegal additives are common contaminants in foods [1]. To ensure food safety, various conventional methods have been developed to determine food contaminants, including traditional plate culture methods, chromatographic methods, enzyme-linked immunosorbent assay (ELISA), and inductively coupled plasma mass spectrometry (ICP-MS). Although these methods demonstrate high accuracy and reliability for detecting food contaminants, they are complicated, time-consuming, and expensive, and they require special equipment and specially trained personnel, which are difficult to meet the requirements for to conduct on-site and rapid screening of massive food samples and are difficult to apply in many places, such as developing countries. Thus, it is urgent to develop rapid, sensitive, low-cost screening methods as complementary ways of ensuring food safety. 
Recently, the fast-growing area of nanomaterials has brought a revolution in the field of analysis and detection, especially with the discovery of nanozymes [2,3]. Nanozymes usually refer to nanomaterials with enzyme-like activities, including the hydrolase and oxidoreductase families. The hydrolase family of nanozymes consists of nuclease- [4], esterase- [5], phosphatase- [6], and protease-like activity [7], while oxidoreductase activity includes peroxidase-, oxidase-, catalase-, and superoxide-dismutase-like activity [8]. Compared with natural enzymes, such as horseradish peroxidase (HRP), nanozymes have several appealing characteristics, such as low cost, high tolerance to harsh conditions (e.g., extreme $\mathrm{pH}$ and temperature), facile surface modification, and multifunctionality [9]. These advantages have attracted increasing research interests over the past decade, in turn elucidating the catalytic mechanism of nanozymes and facilitating the rapid development of the field of nanozymes [10-13]. So far, various nanomaterials, including noble-metal- and transition-metal-based nanomaterials [14-16], carbon-based nanomaterials [17,18], metalorganic framework (MOF)-based nanomaterials [19] and their hybrids, have been found to possess peroxidase-like or/and oxidase-like activity, which can be utilized to directly detect $\mathrm{H}_{2} \mathrm{O}_{2}$, glucose, ascorbic acid, and so on [12,20-22]. Achieving the specific detection of food contaminants usually requires the introduction of molecularly imprinted polymers or biorecognition elements, such as antibodies, antimicrobial peptides, bacteriophages, nucleic acid probes, and aptamers [12,23-25]. Among these, aptamers as alternatives to conventional antibodies are one of the most popular biorecognition elements due to their low cost, facile chemical synthesis, flexible chemical modification, and high tolerance to $\mathrm{pH}$ and temperature [26,27]. Furthermore, specific aptamers for almost all possible targets can be obtained via systematic evolution of ligands by exponential enrichment (SELEX). Up to now, various aptamers were obtained against a wide range of targets, from small molecules such as heavy metals to whole cells such as foodborne pathogens [28,29]. More importantly, aptamers' complementary strands and amplification products are nucleotide sequences, which can reversibly regulate nanozyme activity [30]. These advantages endow nanozyme-based aptasensors with more diversity and promise for food safety applications, especially novel aptasensors based on the regulation by single-stranded DNA (ssDNA) of nanozyme activity.

In view of the extraordinary properties of aptamers and nanozymes, numerous nanozyme-based aptasensors have been developed, and many papers in this field were published in recent years. Although there were several recently published reviews focused on the application of nanozymes in food safety $[11,31,32]$, to the best of our knowledge, systematic reviews specially focusing on nanozyme-aptamer-based biosensors are still rare. To fill this gap, herein, current advances and future prospects of nanozyme-based aptasensors in food safety are systematically discussed. Some factors that govern ssDNA to regulate nanozyme activity are first discussed. Then, the nanozyme-based aptasensors are classified by the different interaction modes of ssDNA and nanozymes, and their applications in food safety are then highlighted. Finally, challenges and prospects for future research in this field are discussed.

\section{Factors Affecting the Regulation by ssDNA of Nanozyme Activity}

The influence of ssDNA on nanozyme activity is complicated. Initially, many research works reported that nanozyme activity was inhibited by ssDNA. As research continued, some groups demonstrated that ssDNA actually improved nanozyme activity [33]. The reasons are yet unclear, but the type of nanozyme and DNA, buffer condition, and temperature in the reaction system were found to be different in these contradicting studies. Hence, to achieve an accurate design of ssDNA-controllable nanozyme biosensors, it is requisite to clearly understand the influence of diverse factors, including intrinsic and extrinsic ones, on the regulation of nanozyme activity by ssDNA (Figure 1). 


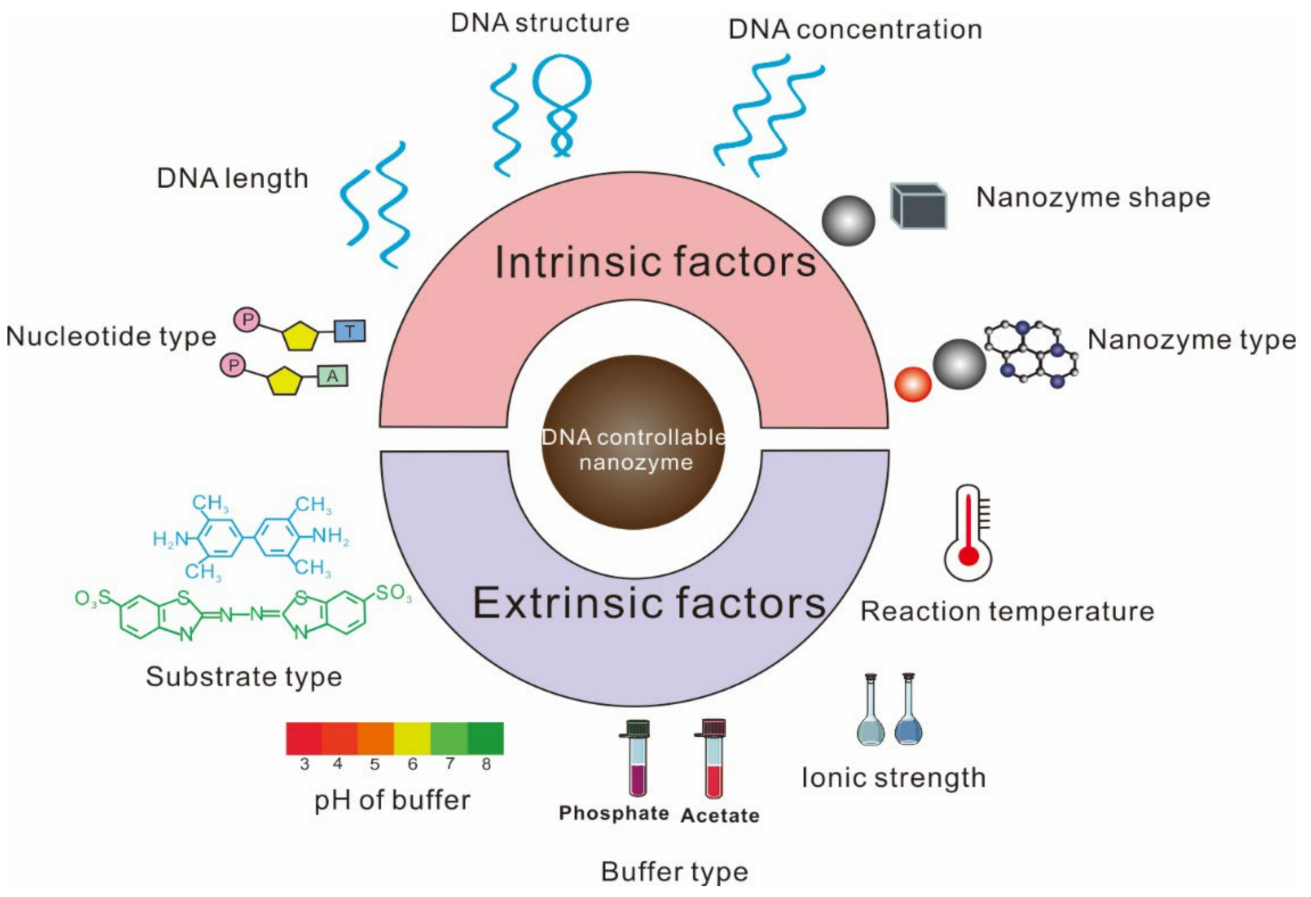

Figure 1. Diverse factors that affect the regulation of ssDNA on nanozyme activity.

\subsection{Factors Affecting ssDNA Inhibition of Nanozyme Activity}

Since nanozyme activity is mainly dependent on their surface properties in the solution, bioconjugation or adsorption of ssDNA on the surface of nanozymes might change the surface properties and affect their activity. In general, adsorbed ssDNA could block the surface active sites or induce the aggregation of nanozymes, thus decreasing the binding sites on nanozymes, resulting in decreased activity $[34,35]$. Thus, the amount of ssDNA aptamer is very important to nanozyme activity. With an increase in aptamer concentration from 2 to $10 \mu \mathrm{M}$, the peroxidase-like activity of graphitic carbon nitride@ $\mathrm{Cu}_{2} \mathrm{O}$ $\left(\mathrm{g}-\mathrm{C}_{3} \mathrm{~N}_{4} @ \mathrm{Cu}_{2} \mathrm{O}\right)$ nanocomposites gradually reduced and finally reached a plateau [36], which indicated the saturation of aptamer on the surface of $\mathrm{g}-\mathrm{C}_{3} \mathrm{~N}_{4} @ \mathrm{Cu}_{2} \mathrm{O}$ when the amount of aptamer increased to $10 \mu \mathrm{M}$. Similar variation trends were observed using Hemin@MOFs nanozyme [37], gold nanoparticles (AuNPs) nanozyme [38], and $\mathrm{MnCo}_{2} \mathrm{O}_{4}$ nanozyme [39]. Different nucleotide types demonstrated different inhibition ability towards nanozyme activity. The order of inhibiting effects towards $\mathrm{MnCo}_{2} \mathrm{O}_{4}$ nanozyme activity was: $A>G>C>T$ [39]. For $\mathrm{Mn}_{3} \mathrm{O}_{4}$ nanozyme, purine nucleotide $(A, G)$ had more active groups to react with octahedral $\mathrm{Mn}_{3} \mathrm{O}_{4}$ nanozymes for blocking surface active sites than pyrimidine nucleotide $(\mathrm{C}, \mathrm{T})$, demonstrating a stronger inhibitory effect on the oxidase-like activity of $\mathrm{Mn}_{3} \mathrm{O}_{4}$ [40]. Theoretically, longer ssDNA would have more binding sites to nanozymes and exhibit a better inhibition effect. In fact, $500 \mathrm{nM}$ of poly $\mathrm{A}_{15}$ was enough to inhibit the oxidase-like activity of $10 \mu \mathrm{g} / \mathrm{mL} \mathrm{MnCo}_{2} \mathrm{O}_{4}$. Increasing the number of nucleotides from 15 to 45 did not cause an obvious change in $\mathrm{MnCo}_{2} \mathrm{O}_{4}$ nanozyme activity, indicating that a saturation of ssDNA was reached on the $\mathrm{MnCo}_{2} \mathrm{O}_{4}$ 's surface [39].

Wang et al. [41] found that double-stranded DNA (dsDNA) did not have the ability to inhibit the oxidase-like activity of a mixed-valence state cerium-based metal-organic framework (MVC-MOF). The difference in ability of ssDNA and dsDNA could be ascribed to the selective adsorption of ssDNA by MVC-MOF [42]. ssDNA has a flexible structure, which contributes to strong $\pi-\pi$ stacking interaction between the bases of ssDNA and MOF. Contrarily, dsDNA has a stiff and rigid double-helix structure and cannot wrap around nanomaterials effectively [37], causing low affinity between dsDNA and nanomaterials. However, when the amount of dsDNA was far more than that of ssDNA, the inhibition effect of the former was comparable to or exceeded that of the latter $[43,44]$. 
The shape of the nanozyme also affects the interaction of ssDNA and nanozymes. For example, compared with other shapes of $\mathrm{Mn}_{3} \mathrm{O}_{4}$ nanoparticles (i.e., flower-like, polyhedron, spinel), octahedral $\mathrm{Mn}_{3} \mathrm{O}_{4}$ nanozymes had more regular surfaces to interact with ssDNA, resulting in a significant inhibition of oxidase-like activity by ssDNA [40]. Adsorption is the first and key step for realizing DNA regulation of nanozyme activity $[45,46]$. Different nanomaterials have different kinds of adsorption force to ssDNA [47]. For example, nanoceria adsorbed onto the ssDNA through electrostatic interaction and Lewis acid-base interaction between the phosphate backbone of ssDNA and cerium [35]. The interaction between DNA and AuNPs was tuned by the combination of various noncovalent forces, including electrostatic interactions, hydrophobic forces, and specific bonds between the chemical groups of DNA bases and gold [48]. In addition, the main adsorption force between graphene and ssDNA was $\pi-\pi$ stacking interaction [49]. Besides nanozyme type, extrinsic conditions affecting the adsorption forces play an important role in nanozyme activity, including $\mathrm{pH}$ and ionic strength. For example, the optimum catalytic condition for $\mathrm{MnCo}_{2} \mathrm{O}_{4}$ nanozyme was $\mathrm{pH} 3.0$, while the nanozyme activity can be maximally inhibited by ssDNA at pH 4.0 [39]. Increasing the ionic strength of buffer weakened the inhibition ability of ssDNA toward $\mathrm{MnCo}_{2} \mathrm{O}_{4}$ nanozyme and enhanced the dissociation ability of ssDNA from the nanozyme's surface [39].

\subsection{Factors Affecting ssDNA to Improve Nanozyme Activity}

With helps from nanotechnology advancement, researchers have found that ssDNA could enhance the catalytic activity of nanomaterials, including noble-metal-based nanomaterials [33], transition-metal-based nanomaterials, carbon-based nanomaterials [50], MOFs, and their hybrids. As mentioned above, the adsorption of ssDNA onto the surface of nanomaterials was a prerequisite for ssDNA to regulate the nanozyme activity. For example, ssDNA on the surface of nanozymes could adsorb more substrate (e.g., 3,3',5,5' tetramethylbenzidine (TMB)) around the nanozyme due to electrostatic attraction and $\pi-\pi$ stacking interaction between TMB and ssDNA, further accelerating electron transfer from TMB to the target sensing molecules (e.g., $\mathrm{H}_{2} \mathrm{O}_{2}$ ) and enhancing the nanozyme activity $[45,51]$. Thus, factors affecting both ssDNA-nanomaterial and ssDNA-TMB affinity are important for the enhancement of nanozyme activity by ssDNA. The usual trend of nanozyme activity was to first increase and then decrease with the increase in ssDNA concentration [52-54]. However, some data support a different variation trend of nanozyme activity, which is to first increase and then keep stable with the increase of ssDNA concentration $[46,50,51,55,56]$. The reason for the two different trends was unclear. We speculate that the presence of excessive ssDNA may hinder the contact of the nanozyme and TMB in the former trend since it had a wide range of ssDNA concentration. DNA molecules with different structures were also reported to affect the peroxidase-like activity of nanozymes. The order of enhancement of the ability of catalytic activity was: hybridization chain reaction (HCR) products (long dsDNA) $>$ hairpin DNA > ssDNA > dsDNA [53]. Moreover, different DNA nucleotides had different abilities to enhance the nanozyme activity. The order of enhancement of $\mathrm{Fe}_{3} \mathrm{O}_{4}$ nanozyme activity was: $\mathrm{C}>\mathrm{G}>\mathrm{T}>\mathrm{A}$ [45]. Cytosine in buffer at $\mathrm{pH} 4.0$ was protonated, which could assist charge neutralization on the surface of $\mathrm{Fe}_{3} \mathrm{O}_{4}$ nanoparticles and reduce repulsion among DNA, leading to the adsorption of more DNA. The same variation trend was observed by Wang et al. [50] using protonated graphitic carbon nitride $\left(\mathrm{Pg}-\mathrm{C}_{3} \mathrm{~N}_{4}\right)$ nanosheets as nanozymes. The peroxidase-like activity of $20 \mathrm{bp}$ homo ssDNA $\left(\mathrm{A}_{20}, \mathrm{C}_{20}, \mathrm{G}_{20}\right.$, and $\left.\mathrm{T}_{20}\right)$ modified $\mathrm{MoS}_{2}$ nanozymes followed the trend of $\mathrm{G}_{20} \approx \mathrm{T}_{20}>\mathrm{A}_{20}>\mathrm{C}_{20}>$ no DNA. The explanation from another perspective was given for the weakest activity of $\mathrm{C}_{20}$-modified $\mathrm{MoS}_{2}$ nanozymes. Protonated cytosine nucleotides in buffer at $\mathrm{pH} 4.0$ increased the electrostatic repulsion between cytosine and positively charged TMB, resulting in a lower affinity of $\mathrm{MoS}_{2}$ nanozymes [51]. Guanine (G) was also reported to significantly enhance the peroxidase-like activity of $\mathrm{WS}_{2}$ nanosheets [57], iron-based MOFs modified with acidized carbon nanotubes (MOF/CNTs) [52], and MIL53(Fe) [46]. Purine (A, G) modification demonstrated a remarkable enhancement of the 
peroxidase-like activity of AuNPs, while pyrimidine (T, C) modification enhanced it slightly, which was attributed to the difference in the interaction between TMB and the surfaceadsorbed nucleobases [58]. In addition, the effect of DNA length on the enhancement of nanozyme activity was also investigated. The longest DNA (ploy $\mathrm{C}_{30}$ ) demonstrated the largest enhancement of peroxidase-like activity of $\mathrm{Fe}_{3} \mathrm{O}_{4}$ nanoparticles due to the presence of more binding sites [45]. Increasing the number of cytosine nucleotides from 30 to 40, the peroxidase-like activity of $\mathrm{Pg}-\mathrm{C}_{3} \mathrm{~N}_{4}$ nanosheets kept steady, which indicated the saturation of ssDNA on the surface of the Pg- $\mathrm{C}_{3} \mathrm{~N}_{4}$ nanosheets [50]. A slight inhibition of the catalytic activity of $\mathrm{MoS}_{2}$ nanozymes was found when the number of thymidine nucleotides increased from 30 to 40 [51].

Besides the intrinsic factors mentioned above, the reaction conditions were also very important for DNA to regulate the nanozyme activity. The buffer $\mathrm{pH}$ at 4.0 had been found to be the optimum condition for both the catalytic activity of nanozymes and the inhibition of nanozyme activity by ssDNA $[45,46,56,57]$. TMB was the most-used substrate in those literatures. It carries positive charges at $\mathrm{pH} 4.0$ that is below its $\mathrm{pKa}$, which is beneficial to the reaction between ssDNA and TMB [45]. However, continuously reducing the $\mathrm{pH}$ resulted in the protonation of two amino acids of TMB, which made them insusceptible to oxidation [59]. Moreover, buffer type and concentration were also reported to affect the ability of ssDNA to enhance the peroxidase-like activity of nanozymes. In a phosphate buffer, low-concentration DNA moderately increased the peroxidase-like activity of $\mathrm{CeO}_{2}$, while DNA in acetate buffer had no effect on the catalytic activity of $\mathrm{CeO}_{2}$, except for the high-concentration DNA (more than $10 \mu \mathrm{M}$ ), which inhibited the $\mathrm{CeO}_{2}$ nanozyme activity [60]. This was because phosphate could compete with ssDNA to bind to $\mathrm{CeO}_{2}$ nanozymes and enhance their peroxidase-like activity. Low ionic strength increased the peroxidase-like activity of ssDNA-modified $\mathrm{WS}_{2}$ nanosheets [57], while high ionic strength could shield the electrostatic reaction, which reduced the interaction among ssDNA, nanozymes, and TMB [61].

More amazingly, the enhancement or inhibition of the peroxidase-like activity of AuNPs by ssDNA can be controlled by $\mathrm{H}_{2} \mathrm{O}_{2}$ concentration. In a $10 \mathrm{mM} \mathrm{H}_{2} \mathrm{O}_{2}$ reaction system, DNA inhibited the peroxidase-like activity of AuNPs in the first $10 \mathrm{~min}$ and enhanced the catalytic activity of AuNPs in the next $20 \mathrm{~min}$ of the reaction time, while at a lower concentration of $\mathrm{H}_{2} \mathrm{O}_{2}(5 \mathrm{mM})$, it prolonged the inhibition time to 30 min and enhancement occurred after $30 \mathrm{~min}$ [58]. Moreover, by changing the substrate from the positively charged TMB to the negatively charged 2,2'-azino-bis (3-ethyl benzothiazoline6-sulfonic acid) (ABTS), the enhanced ability of ssDNA disappeared, and the inhibiting ability of ssDNA appeared $[45,57]$.

As previously mentioned, ssDNA can either enhance or inhibit the catalytic activity of nanozymes, and the deciding factor for enhancement or inhibition was to increase or decrease the affinity of substrate (e.g., TMB or ABTS) and nanozymes, respectively, by the introduction of ssDNA. A small change of these factors caused the interaction of ssDNA and nanozymes to be altered, which resulted in variations of the nanozyme activity. Thus, the process of designing aptamer-assisted nanozyme sensing needs to be thoughtful since various factors can affect the regulation of ssDNA on nanozyme activities.

\section{Nanozyme-Based Aptasensors}

In recent years, the application of nanozyme-based aptasensors in food has safety become more and more popular, especially DNA-controllable nanozyme aptasensors. Some of them have been validated in food products, and some have the potential to be used for food samples. In this section, nanozyme-based aptasensors divided into four categories-nanozyme activity inhibited by ssDNA, nanozyme activity enhanced by ssDNA, nanozymes as signal tags, and other methods-are discussed. 


\subsection{Nanozyme Activity Inhibited by ssDNA}

In this section, nanozyme activity inhibited by ssDNA was thoroughly discussed, which was dependent on the amount of contaminants in food. Based on the inhibition of nanozyme activity by ssDNA, Sharma et al. [34] developed a "turn-off-on" biosensor strategy based on the peroxidase-like activity of AuNPs and ssDNA Ky2 aptamer for detecting kanamycin. The ssDNA Ky2 aptamer adsorbed onto the surface of AuNPs and blocked the catalytic sites of the AuNPs, resulting in the inhibition of the peroxidase-like activity of AuNPs in the presence of TMB- $\mathrm{H}_{2} \mathrm{O}_{2}$. Conversely, the presence of kanamycin induced the release of ssDNA Ky2 aptamer from the AuNPs due to the specific binding between kanamycin and aptamer. Subsequently, the catalytic activity of the AuNPs recovered, and the solution exhibited a blue color. By measuring the change in absorbance at $650 \mathrm{~nm}$, this aptasensor demonstrated highly sensitive quantitative detection of kanamycin with a limit of detection (LOD) and limit of quantitation (LOQ) of $1.49 \mathrm{nM}$ and $4.52 \mathrm{nM}$, respectively. This nanozyme-based aptasensor strategy is available for monitoring other food contaminants, such as Salmonella typhimurium [36,62], Campylobacter jejuni [63], zearalenone [64], sulfadimethoxine [65], chlorpyrifos [66], chloramphenicol [67], acetamiprid [68], Hg(II) [69], norovirus [38], and oxytetracycline [70]. Besides the TMB substrate, the same inhibition phenomenon was observed using negatively charged ABTS as a substrate and AuNPs as nanozymes for detecting streptomycin [71] and acetamiprid [72]. In addition, two convenient chemiluminescence aptasensors were developed for detecting bisphenol A [73] and acetamiprid [74], respectively. In recent year, an ultrasensitive and practical chemiluminescence aptasensor was constructed for detecting acetamiprid by combining the synergistic co-catalysis of graphene oxide (GO)/AuNPs with dexterous interface engineering based on DNA dimensional structure [75]. Due to the high catalytic activity of GO/AuNPs and the perfect regulation of the GO/AuNPs composite interface by DNA dimension, this chemiluminescence sensing demonstrated an ultrahigh sensitivity, with a LOD of 8.9 pM.

However, some researchers found that peroxidase was not the best candidate to study the inhibition effect of ssDNA aptamer on nanozyme activity. This was because the substrate $\left(\mathrm{H}_{2} \mathrm{O}_{2}\right)$ can generate hydroxyl radicals during the catalytic process which induce DNA cleavage. Considering the high toxicity of the hydroxyl radical to DNA, Wang et al. [41] developed a colorimetric sensor for $\mathrm{Hg}$ (II) detection based on the inhibition of the oxidase-like activity of MVC-MOF by thymine-rich ssDNA but not thymine-rich dsDNA. Under optimal conditions, the LOD was $10.5 \mathrm{nM}$ based on $\mathrm{S} / \mathrm{N}=3$, and high selectivity was verified by comparing the signals from other ions' detection. In another research, octahedral $\mathrm{Mn}_{3} \mathrm{O}_{4}$ nanozymes were also reported to selectively adsorb T-rich ssDNA and were designed to detect $\mathrm{Hg}$ (II) and $\mathrm{Cd}(\mathrm{II})$ [40]. Using the same nanozyme, Zhu et al. [76] proposed an ultrasensitive colorimetric aptasensor for detecting $S$. aureus with a LOD of 3 CFU/mL. Moreover, Huang et al. [39] utilized ochratoxin A (OTA) aptamer to inhibit the oxidase-like activity of $\mathrm{MnCo}_{2} \mathrm{O}_{4}$ for realizing OTA in maize detection, with a LOD of $0.08 \mathrm{mM}$.

Since TMB is an electrochemically active species, colorimetric methods based on the oxidation of TMB are able to be translated into electrochemical signals for realizing ultrasensitive detection. Das et al. [77] adopted a screen-printed electrode to measure an electrochemically active product via catalyzing TMB oxidation for realizing $60 \mathrm{CFU} / \mathrm{mL}$ for detecting Pseudomonas aeruginosa. A similar strategy was also proposed for detecting Escherichia coli in apple juice in $2 \mathrm{~min}$, with a LOD of $10 \mathrm{CFU} / \mathrm{mL}$ [78]. Thionine is also a redox probe and is widely used in electrochemical detection. Wang et al. [79] utilized AuNPs to catalyze the reaction between $\mathrm{H}_{2} \mathrm{O}_{2}$ and thionine to produce oxidized thionine for realizing kanamycin detection with a sensitivity limit of $0.06 \mathrm{nM}$.

Taghdisi et al. [80] developed a novel aptasensor for $\mathrm{Pb}$ (II) detection based on a triplehelix molecular switch (THMS) and the peroxidase-like activity of AuNPs. As shown in Figure 2A, the two arm segments of $\mathrm{Pb}(\mathrm{II})$ aptamer reacted with STP sequence through Watson-Crick and Hoogsteen base pairings to form THMS, which could not adsorb onto the surface of AuNPs. Thus, the AuNPs, with their intrinsic peroxidase-like activity, catalyzed 
TMB to produce a blue color with the help of $\mathrm{H}_{2} \mathrm{O}_{2}$. However, the presence of $\mathrm{Pb}$ (II) caused the formation of $\mathrm{Pb}$ (II)-aptamer complexes, and the released STP was able to adsorb onto the surface of the AuNPs to inhibit their peroxidase-like activity. The proposed aptasensor achieved a LOD of $602 \mathrm{pM}$ in a pure aqueous solution. Furthermore, this biosensor was validated in tap water and serum with LODs of 0.708 and $2.07 \mathrm{nM}$, respectively. Recently, Dehghani et al. [81] integrated magnetic separation, loop mediated isothermal amplification (LAMP), and Pt/Pd nanozymes into one method for on-site detection of $S$. typhimurium (Figure 2B). Dual-functional magnetic beads were first constructed by modifying both $S$. typhimurium aptamers and polyethylene glycol (PEG)-coupled Pt/Pd nanozymes, which were capable to capture bacteria using specific aptamers and output detection signals using the $\mathrm{Pt} / \mathrm{Pd}$ nanozymes. After magnetic separation, abundant target DNA of $S$. typhimurium was obtained by LAMP to adsorb onto the surface of the Pt/Pd nanozymes, leading to the inhibition of $\mathrm{Pt} / \mathrm{Pd}$ nanozyme activity. This unique method could detect 10-15 CFU/mL of bacteria in a chicken meat sample and 3-10 CFU/mL of bacteria in both whole egg and chicken fecal samples within less than $3 \mathrm{~h}$.

In addition, AuNPs can also catalyze 4-nitrophenol to produce 4-aminophenol in the presence of $\mathrm{NaBH}_{4}$, resulting in the color change of the solution from yellow to colorless. Combining with the catalytic activity of AuNPs, Lavaee et al. [82] developed a colorimetric aptasensor for fluoroquinolones based on the inhibition of catalytic activity of AuNPs by flower-shaped structures. As shown in Figure 2C, both complementary strand 1 of the aptamer (CS1) and complementary strand 2 of the aptamer (CS2) were modified on the surface of AuNPs via Au-S bond. Then, both ends of the aptamer were hybridized with CS1 and CS2, forming a flower-shaped structure on the surface of AuNPs to inhibit the catalytic activity of the AuNPs. However, the presence of ciprofloxacin led to release of the aptamer from the AuNPs, thus resuming the catalytic activity of the AuNPs. By validating in spiked samples, the aptasensor demonstrated high sensitivity, with LODs of $1.3,2.6$, and $3.2 \mathrm{nM}$ in spiked water, serum, and milk samples, respectively, with $1 \mathrm{~h}$ analysis time. Subsequently, a colorimetric aptasensor for zearalenone detection was developed by integrating nontarget-induced aptamer walker, the peroxidase-like activity of AuNPs, and exonuclease-assisted recycling amplification [83]. As shown in Figure 2D, both aptamers and the complementary strands were modified on the surface of AuNPs and hybridized with each other to form dsDNA between a portion of aptamer nucleotides and the complementary strand. Then, Exo III nucleases degraded the blunt $3^{\prime}$-terminus of the complementary strand, and the released aptamers bound to other complementary strands, followed by the second degradation process. After numerous degradation processes, the size of the ssDNA-modified AuNPs reduced. Finally, the 4-nitrophenol easily touched the exposed surface of AuNPs and was reduced with the help of $\mathrm{NaBH}_{4}$, resulting in the color change of the solution from yellow to colorless. In the presence of zearalenone, the aptamers bound to zearalenone, and the complementary strands could not be degraded. Only a small amount of 4-nitrophenol reached the surface of the AuNPs due to the steric hindrance of aptamer-zearalenone complexes and intact complementary strands on the surface of AuNPs. The solution remained yellow. By measuring the absorbance at $400 \mathrm{~nm}$, the proposed aptasensor detected zearalenone in a wide linear dynamic range from 20 to $80,000 \mathrm{nM}$, with a LOD of $10 \mathrm{nM}$.

In addition, Abnous et al. [84] integrated CRISPR-Cas12a, rolling circle amplification, and the catalytic activity of AuNPs into a colorimetric aptasensor for ultrasensitive detection of aflatoxin M1 (AFM1). As shown in Figure 2E, in the presence of AFM1, aptamers cannot bind to the inactivated CRISPR-Cas12a due to aptamer-AFM1's specific binding. Then, the inactivated CRISPR-Cas12a cannot conduct trans-cleavage of primer. Intact primermodified AuNPs went through two enzyme reactions (T4 DNA ligase and phi29 DNA polymerase) to yield abundant and long DNA structures on the surface of AuNPs, which hindered the entry of 4-nitrophenol to the surface of the AuNPs. Thus, the solution remained yellow. When AFM1 was absent, CRISPR-Cas12a was activated through the combination of aptamer and CRISPR-Cas12a, which degraded the primer modified on the 
surface of the AuNPs. Consequently, long ssDNA could not be produced on the surface of AuNPs through two enzyme reactions. Finally, 4-nitrophenol was easily able to reach the surface of the AuNPs, and the solution changed from yellow to colorless. The novel aptasensor achieved a LOD of $0.05 \mathrm{nM}$ in a pure aqueous solution and $0.15 \mathrm{nM}$ in a milk sample. The nanozyme-based aptasensors based on the inhibition of nanozyme activity by ssDNA are listed in Table 1.
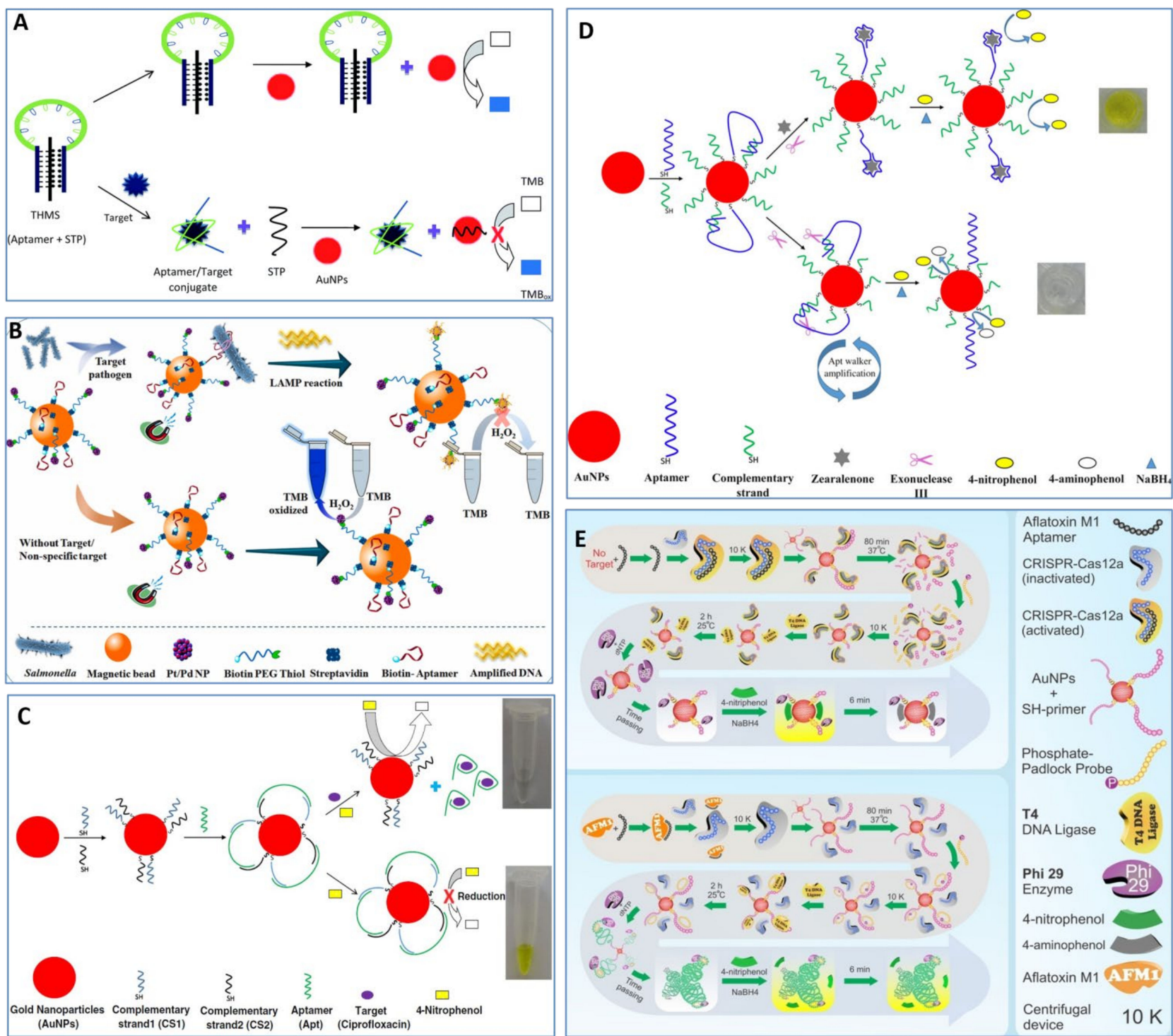

Figure 2. Examples of aptasensor based on the inhibition of nanozyme activity by ssDNA. (A) A novel colorimetric triple-helix molecular switch aptasensor for $\mathrm{Pb}$ (II) based on the peroxidase-like activity of gold nanoparticles. Reprinted with permission from reference [80]. (B) A colorimetric method for $S$. typhimurium based on DNA-mediated inhibition of the peroxidase-like activity of $\mathrm{Pt} / \mathrm{Pd}$ nanoparticles, loop-mediated isothermal amplification, and magnetic separation. Reprinted with permission from reference [81]. (C) A colorimetric aptasensor for ciprofloxacin detection by triggering the reduction-catalyzing activity of gold nanoparticles. Reprinted with permission from reference [82]. (D) A colorimetric aptasensor for zearalenone detection based on Exo III-assisted aptamer walker and catalytic reaction of AuNPs. Reprinted with permission from reference [83]. Copyright 2018 American Chemical Society. (E) A novel colorimetric aptasensor for ultrasensitive detection of AFM1 based on the combination of CRISPR-Cas12a, rolling circle amplification, and catalytic activity of gold nanoparticle. Reprinted with permission from reference [84]. 
Table 1. Nanozyme-based aptasensors based on the inhibition of nanozyme activity by ssDNA.

\begin{tabular}{|c|c|c|c|c|c|c|c|c|}
\hline S. No. & Contaminants & Nanozymes & Substrates & $\begin{array}{c}\text { Nanozyme Reaction } \\
\text { Condition (Buffer, } \\
\text { Temperature, } \\
\text { Reaction Time) }\end{array}$ & Sensitivity & Sample Matrix & Linear Range & References \\
\hline 1 & Kanamycin & AuNPs & $\mathrm{TMB} / \mathrm{H}_{2} \mathrm{O}_{2}$ & - & $1.49 \mathrm{nM}$ & - & 1 to $100 \mathrm{nM}$ & [34] \\
\hline 2 & S. typhimurium & $\begin{array}{c}\mathrm{Fe}_{3} \mathrm{O}_{4} \\
\text { nanoparticles }\end{array}$ & $\mathrm{TMB} / \mathrm{H}_{2} \mathrm{O}_{2}$ & $\begin{array}{c}0.1 \mathrm{M} \text { acetate buffer ( } \mathrm{pH} 4.0) \\
42^{\circ} \mathrm{C}, 10 \mathrm{~min}\end{array}$ & $\begin{array}{l}7.5 \times 10^{5} \\
\mathrm{CFU} / \mathrm{mL}\end{array}$ & - & - & [62] \\
\hline 3 & S. typhimurium & $\begin{array}{c}\text { g- } \mathrm{C}_{3} \mathrm{~N}_{4} @ \mathrm{Cu}_{2} \mathrm{O} \\
\text { composites }\end{array}$ & $\mathrm{TMB} / \mathrm{H}_{2} \mathrm{O}_{2}$ &,,$-- 6 \mathrm{~min}$ & $15 \mathrm{CFU} / \mathrm{mL}$ & Milk & $\begin{array}{l}15 \text { to } 1.5 \times 10^{5} \\
\mathrm{CFU} / \mathrm{mL}\end{array}$ & [36] \\
\hline 4 & C. jejuni & $\begin{array}{c}\text { Au@Pd } \\
\text { nanoparticles }\end{array}$ & $\mathrm{TMB} / \mathrm{H}_{2} \mathrm{O}_{2}$ & $\begin{array}{c}20 \text { mM phosphate buffer } \\
\text { (pH 7.0), -, - }\end{array}$ & $100 \mathrm{CFU} / \mathrm{mL}$ & Milk & 10 to $10^{6} \mathrm{CFU} / \mathrm{mL}$ & [63] \\
\hline 5 & Zearalenone & AuNPs & $\mathrm{TMB} / \mathrm{H}_{2} \mathrm{O}_{2}$ & $-, 25^{\circ} \mathrm{C}, 15 \mathrm{~min}$ & $10 \mathrm{ng} / \mathrm{mL}$ & Corn and corn oil & 10 to $250 \mathrm{ng} / \mathrm{mL}$ & [64] \\
\hline 6 & Sulfadimethoxine & AuNPs & $\mathrm{TMB} / \mathrm{H}_{2} \mathrm{O}_{2}$ &,,$-- 10 \mathrm{~min}$ & $10 \mathrm{ng} / \mathrm{mL}$ & Milk & $\begin{array}{c}0.01 \text { to } 1000 \\
\mu \mathrm{g} / \mathrm{mL}\end{array}$ & [65] \\
\hline 7 & Chlorpyrifos & $\begin{array}{c}\text { Tyrosine-capped } \\
\text { silver } \\
\text { nanoparticles }\end{array}$ & $\mathrm{TMB} / \mathrm{H}_{2} \mathrm{O}_{2}$ & $37^{\circ} \mathrm{C},-, 2 \mathrm{~min}$ & $11.3 \mathrm{ppm}$ & River water & 35 to $210 \mathrm{ppm}$ & [66] \\
\hline 8 & Chloramphenicol & Iron-based MOFs & $\mathrm{TMB} / \mathrm{H}_{2} \mathrm{O}_{2}$ & $\begin{array}{l}0.1 \mathrm{M} \mathrm{NaAc}-\mathrm{HAc} \text { buffer } \\
(\mathrm{pH} 3.0), 40{ }^{\circ} \mathrm{C}, 20 \mathrm{~min}\end{array}$ & $25 \mathrm{nM}$ & Tap water & 50 to $200 \mathrm{nM}$ & [67] \\
\hline 9 & Acetamiprid & AuNPs & $\mathrm{TMB} / \mathrm{H}_{2} \mathrm{O}_{2}$ & $-, 37^{\circ} \mathrm{C}, 10 \mathrm{~min}$ & $0.1 \mathrm{ppm}$ & - & 2.5 to $25 \mathrm{ppm}$ & [68] \\
\hline 10 & $\mathrm{Hg}(\mathrm{II})$ & $\begin{array}{c}\mathrm{Fe}_{3} \mathrm{O}_{4} \\
\text { nanoparticles }\end{array}$ & $\mathrm{TMB} / \mathrm{H}_{2} \mathrm{O}_{2}$ & $\begin{array}{c}0.2 \mathrm{M} \text { acetate buffer }(\mathrm{pH} 4.0) \\
25^{\circ} \mathrm{C}, 10 \mathrm{~min}\end{array}$ & $5 \mu \mathrm{M}$ & - & 5 to $75 \mu \mathrm{M}$ & [69] \\
\hline 11 & Murine norovirus & AuNPs & $\mathrm{TMB} / \mathrm{H}_{2} \mathrm{O}_{2}$ &,,$-- 10 \mathrm{~min}$ & 30 viruses $/ \mathrm{mL}$ & $\begin{array}{c}\text { Human serum and } \\
\text { shellfish } \\
\text { homogenate }\end{array}$ & $\begin{array}{l}200 \text { to } 10,000 \\
\text { viruses } / \mathrm{mL}\end{array}$ & [38] \\
\hline 12 & Oxytetracycline & $\begin{array}{c}\text { Graphene-gold } \\
\text { nanoparticle } \\
\text { hybrid }\end{array}$ & $\mathrm{TMB} / \mathrm{H}_{2} \mathrm{O}_{2}$ & Citrate buffer (pH 4.0), -, - & $0.91 \mathrm{nM}$ & - & 0.17 to $0.5 \mu \mathrm{M}$ & [70] \\
\hline 13 & Streptomycin & AuNPs & ABTS $/ \mathrm{H}_{2} \mathrm{O}_{2}$ & $\begin{array}{l}5 \mathrm{mM} \text { sodium acetate } \\
(\mathrm{pH} 4.5), 30^{\circ} \mathrm{C}, 10 \mathrm{~min}\end{array}$ & $86 \mathrm{nM}$ & Milk & 0.1 to $0.5 \mu \mathrm{M}$ & [71] \\
\hline
\end{tabular}


Table 1. Cont.

\begin{tabular}{|c|c|c|c|c|c|c|c|c|}
\hline S. No. & Contaminants & Nanozymes & Substrates & $\begin{array}{c}\text { Nanozyme Reaction } \\
\text { Condition (Buffer, } \\
\text { Temperature, } \\
\text { Reaction Time) } \\
\end{array}$ & Sensitivity & Sample Matrix & Linear Range & References \\
\hline 14 & Acetamiprid & AuNPs & ABTS $/ \mathrm{H}_{2} \mathrm{O}_{2}$ & $\begin{array}{c}3.5 \mathrm{mM} \text { NaAc-HAc buffer } \\
(\mathrm{pH} 5.0),-,-\end{array}$ & $1.02 \mu \mathrm{g} / \mathrm{L}$ & $\begin{array}{l}\text { Wastewater and } \\
\text { tomatoes }\end{array}$ & 10 to $160 \mathrm{ng} / \mathrm{mL}$ & {$[72]$} \\
\hline 15 & Bisphenol A & Cationic AuNPs & Luminol/ $\mathrm{AgNO}_{3}$ &,,--- & $62 \mathrm{pg} / \mathrm{mL}$ & $\begin{array}{c}\text { Soil of an } \\
\text { electronic waste } \\
\text { dismantling area }\end{array}$ & 0.1 to $40 \mathrm{ng} / \mathrm{mL}$ & [73] \\
\hline 16 & Acetamiprid & AuNPs & Luminol $/ \mathrm{H}_{2} \mathrm{O}_{2}$ &,,--- & $62 \mathrm{pM}$ & $\begin{array}{l}\text { Wastewater, soil, } \\
\text { and cucumber }\end{array}$ & 0.8 to $6.3 \times 10^{2} \mathrm{nM}$ & [74] \\
\hline 17 & Acetamiprid & GO/AuNPs & Luminol $/ \mathrm{H}_{2} \mathrm{O}_{2}$ &,,--- & $8.9 \mathrm{pM}$ & $\begin{array}{l}\text { Wastewater, soil } \\
\text { samples, } \\
\text { cucumber, and } \\
\text { apple }\end{array}$ & $\begin{array}{l}2.1 \times 10^{-2} \text { to } \\
9 \mathrm{nM}\end{array}$ & [75] \\
\hline 18 & $\mathrm{Hg}(\mathrm{II})$ & $\begin{array}{l}\text { MVC-MOF } \\
\text { nanomaterials }\end{array}$ & TMB & $\begin{array}{c}50 \mathrm{mM} \mathrm{NaAc-HAc} \mathrm{buffer} \\
(\mathrm{pH} 4.0) \text {, room temperature, } \\
30 \mathrm{~min}\end{array}$ & $10.5 \mathrm{nM}$ & $\begin{array}{l}\text { Environmental } \\
\text { water }\end{array}$ & 0.05 to $6 \mu \mathrm{M}$ & [41] \\
\hline 19 & $\begin{array}{l}\mathrm{Hg}(\mathrm{II}) \\
\mathrm{Cd}(\mathrm{II})\end{array}$ & $\begin{array}{c}\text { Octahedral } \mathrm{Mn}_{3} \mathrm{O}_{4} \\
\text { nanoparticles }\end{array}$ & TMB & $25 \mathrm{mM}$ acetate buffer (pH 3.0), & $\begin{array}{l}3.8 \mu \mathrm{g} / \mathrm{L} \\
2.4 \mu \mathrm{g} / \mathrm{L}\end{array}$ & $\begin{array}{l}\text { Tap water, river } \\
\text { water, lake water, }\end{array}$ & $\begin{array}{c}10 \text { to } 200 \mu \mathrm{g} / \mathrm{L} \\
5 \text { to } 100 \mu \mathrm{M}\end{array}$ & [40] \\
\hline 20 & S. aureus & $\begin{array}{c}\text { Octahedral } \mathrm{Mn}_{3} \mathrm{O}_{4} \\
\text { nanoparticles }\end{array}$ & TMB & $\begin{array}{c}20 \mathrm{mM} \mathrm{NaAc}(\mathrm{pH} 3.5), \text { at } \\
\text { room temperature, - }\end{array}$ & $3 \mathrm{CFU} / \mathrm{mL}$ & $\begin{array}{l}\text { and waste water } \\
\text { Milk and pork }\end{array}$ & $\begin{array}{c}10 \text { to } 2 \times 10^{5} \\
\mathrm{CFU} / \mathrm{mL}\end{array}$ & [76] \\
\hline 21 & OTA & $\begin{array}{c}\mathrm{MnCo}_{2} \mathrm{O}_{4} \\
\text { submicrospheres }\end{array}$ & TMB & $\begin{array}{c}0.1 \mathrm{M} \text { acetate buffer ( } \mathrm{pH} 4.0) \\
-, 10 \mathrm{~min}\end{array}$ & $0.08 \mathrm{ng} / \mathrm{mL}$ & Maize & 0.1 to $10 \mathrm{ng} / \mathrm{mL}$ & [39] \\
\hline 22 & P. aeruginosa & AuNPs & $\mathrm{TMB} / \mathrm{H}_{2} \mathrm{O}_{2}$ &,,--- & $60 \mathrm{CFU} / \mathrm{mL}$ & Water & $\begin{array}{l}60.0 \text { to } 6.0 \times 10^{7} \\
\quad \mathrm{CFU} / \mathrm{mL}\end{array}$ & [77] \\
\hline 23 & E. coli & AuNPs & $\mathrm{TMB} / \mathrm{H}_{2} \mathrm{O}_{2}$ & - , at room temperature, $2 \mathrm{~min}$ & $10 \mathrm{CFU} / \mathrm{mL}$ & Apple juice & 10 to $10^{9} \mathrm{CFU} / \mathrm{mL}$ & [78] \\
\hline 24 & Kanamycin & AuNPs & Thionine $/ \mathrm{H}_{2} \mathrm{O}_{2}$ & $\begin{array}{c}2 \mathrm{mM} \mathrm{Hac}-\mathrm{NaAc} \text { buffer }(\mathrm{pH} \\
4.0), 40^{\circ} \mathrm{C}, 20 \mathrm{~min}\end{array}$ & $0.06 \mathrm{nM}$ & Honey & 0.1 to $60 \mathrm{nM}$ & {$[79]$} \\
\hline
\end{tabular}


Table 1. Cont.

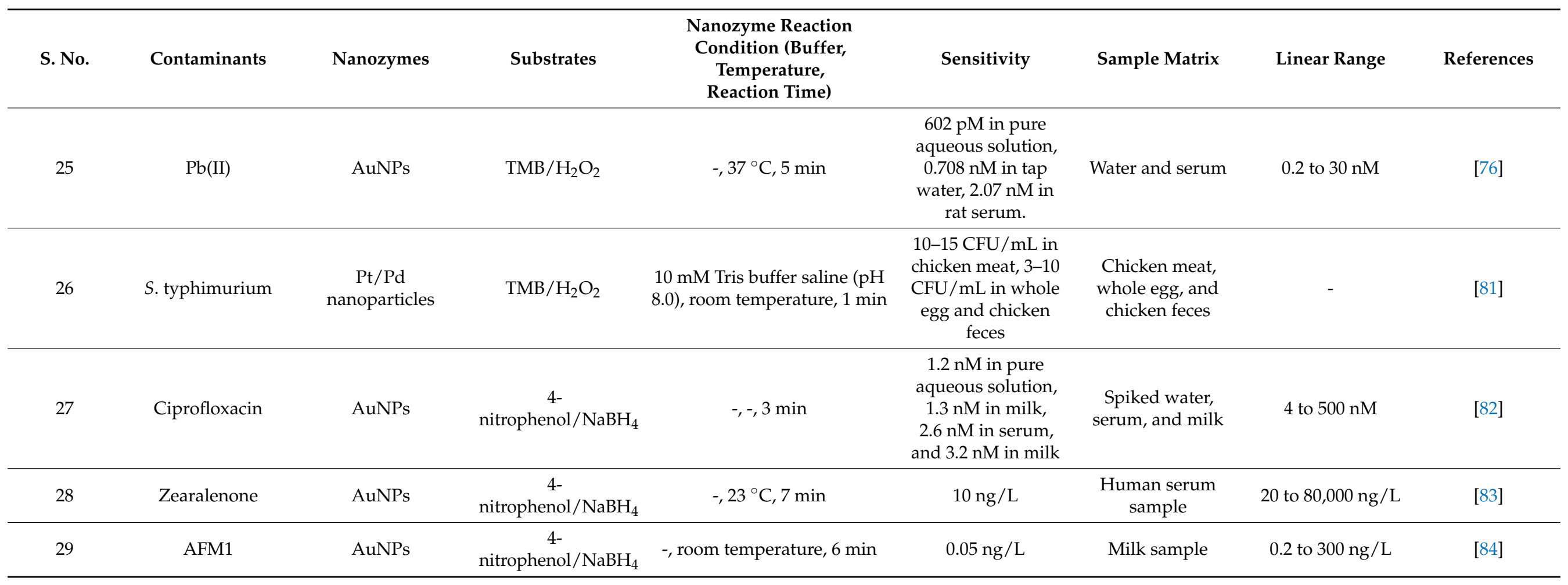


As mentioned above, enormous efforts have been made to develop aptasensors based on the inhibition of nanozyme activity by ssDNA for the detection of food contaminants. However, many of the components in food matrixes can adsorb onto the surface of nanozymes and inhibit the peroxidase-like activity of the nanozymes, resulting in low sensitivity or even false positive results for these aptasensors. High-efficiency sample pretreatment incorporated into the nanozyme-based aptasensor, which can minimize the influence of food components on the nanozyme activity, would be a good strategy for high-sensitivity detection of food contaminants.

\subsection{Nanozyme Activity Enhanced by ssDNA}

Aside from those mentioned above, various aptasensor strategies based on the enhancement of nanozyme activity by ssDNA have been proposed. Zhu et al. [56] used aptamers to enhance the peroxidase-like activity of boron nitride quantum dots-anchored porous $\mathrm{CeO}_{2}$ nanorods (BNQDs $/ \mathrm{CeO}_{2}$ ) to achieve $4.6 \mathrm{pM}$ kanamycin detection (Figure 3A). The $\mathrm{BNQDs} / \mathrm{CeO}_{2}$ nanozymes showed peroxidase-like activity, while integrating $\mathrm{BNQDs} / \mathrm{CeO}_{2}$ nanozymes with kanamycin aptamers demonstrated obviously enhanced catalytic activity. However, the presence of kanamycin could inhibit such catalytic enhancement due to the specific binding between aptamer and kanamycin. Thus, the detection signal was negatively correlated with the concentration of the target. Similar mechanisms were also applied for the detection of tetracycline [85], kanamycin [57], sulfadimethoxine [86], cocaine [87], abrin [88], malachite green [89], and Streptococcus pneumoniae [90]. In addition, Wang et al. [50] developed a versatile ratiometric fluorescence platform for detecting $\mathrm{Hg}(\mathrm{II})$ and aflatoxin B1 (AFB1) based on the enhancement of peroxidase-like activity of $\mathrm{Pg}-\mathrm{C}_{3} \mathrm{~N}_{4}$ nanosheets by ssDNA. As shown in Figure $3 \mathrm{~B}, \mathrm{Pg}-\mathrm{C}_{3} \mathrm{~N}_{4}$ nanosheets had a maximum fluorescence emission of $443 \mathrm{~nm}$ under excitation at $370 \mathrm{~nm}$. Subsequent adsorption of aptamer onto the surface of $\mathrm{Pg}-\mathrm{C}_{3} \mathrm{~N}_{4}$ nanosheets did not change the fluorescence intensity but greatly improved their peroxidase-like activity. The high peroxidase-like activity of aptamer $/ \mathrm{Pg}-\mathrm{C}_{3} \mathrm{~N}_{4}$ complexes could accelerate the catalysis reaction between ophenylenediamine (OPD) and $\mathrm{H}_{2} \mathrm{O}_{2}$ to produce more 2,3-diaminophenazine (DAP), which quenched the fluorescence of aptamer $/ \mathrm{Pg}-\mathrm{C}_{3} \mathrm{~N}_{4}$ complexes at $443 \mathrm{~nm}$ and generated a new emission peak at $564 \mathrm{~nm}$. However, the presence of target molecules induced the dissociation of aptamers from $\mathrm{Pg}-\mathrm{C}_{3} \mathrm{~N}_{4}$ nanosheets, resulting in low peroxidase-like activity of the $\mathrm{Pg}-\mathrm{C}_{3} \mathrm{~N}_{4}$ nanosheets. Then, the fluorescence intensity increased at $443 \mathrm{~nm}$, and the fluorescence intensity decreased at $564 \mathrm{~nm}$. By measuring the change in the fluorescence intensity ratio $\left(\mathrm{I}_{443} / \mathrm{I}_{564}\right)$, the versatile ratiometric fluorescence platform achieved $0.01 \mathrm{nM} \mathrm{Hg}(\mathrm{II})$ and a $0.01 \mathrm{pg} / \mathrm{mL}$ AFB1 detection limit using AFB1 aptamer. Yang et al. [91] developed a facile label-free colorimetric aptasensor for acetamiprid detection based on the peroxidase-like activity of hemin-functionalized reduced graphene oxide (hemin-rGO) (Figure 3C). Aptamers adsorbed onto the surface of hemin-rGO had an ability to increase the individual hemin-rGO electrostatic repulsion and hinder the coagulation of heminrGO in the presence of salt. Thereafter, all hemin-rGO in the supernatant catalyzed TMB in the presence of $\mathrm{H}_{2} \mathrm{O}_{2}$ to produce a blue color. However, the presence of acetamiprid led to the formation of acetamiprid-aptamer complexes, preventing the aptamers from adsorbing onto hemin-rGO. Therefore, hemin-rGO aggregated under salt stress conditions, and little hemin-rGO remained in the supernatant after centrifugation. Thus, the color of the supernatant did not change. Under optimized conditions, the LOD reached $40 \mathrm{nM}$. Similar methods were reported to detect bisphenol A using hemin-rGO nanozymes [92], as well as $\mathrm{Hg}$ (II) and $\mathrm{Pb}$ (II) using the peroxidase-like activity of GO-AuNP nanohybrids [93]. Moreover, RNA aptamers were also found preventing the hexadecyltrimethyl ammonium bromide (CTAB)-induced aggregation of AuNPs and improving the peroxidase-like activity of AuNPs. Utilizing this characteristic, a colorimetric aptasensor based on the inhibition of the peroxidase-like activity of AuNPs by CTAB was developed for the detection of malachite green, with a LOD of $1.8 \mathrm{nM}$ [94]. 

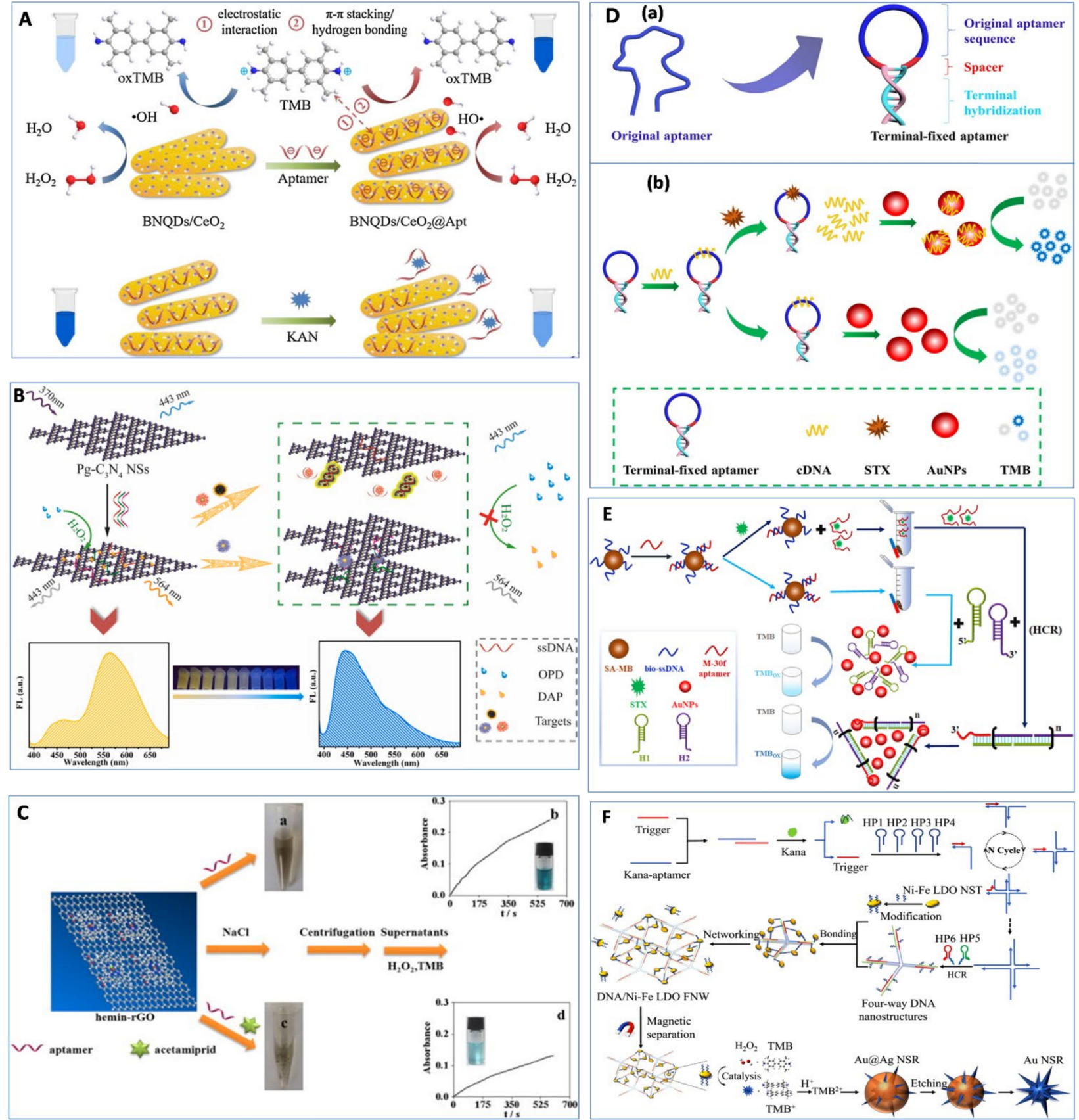

Figure 3. Examples of aptasensor based on the enhancement of nanozyme activity by ssDNA. (A) A colorimetric method for kanamycin detection based on the enhancement of the peroxidaselike activity of $\mathrm{BNQDs} / \mathrm{CeO}_{2}$ by aptamer. Reprinted with permission from reference [56]. (B) A versatile ratiometric fluorescence platform based on the enhancement of peroxidase-like activity of $\mathrm{Pg}-\mathrm{C}_{3} \mathrm{~N}_{4}$ nanosheets by ssDNA. Reprinted with permission from reference [50]. (C) A facile label-free colorimetric aptasensor for acetamiprid detection based on the peroxidase-like activity of hemin-rGO. Reprinted with permission from reference [91]. (D) A colorimetric detection for saxitoxin based on a terminal-fixed aptamer and the peroxidase-like activity of AuNPs. Reprinted with permission from reference [95]. (a) The design of the terminal-fixed aptamer, (b) Principle of the colorimetric biosensor. (E) A competitive colorimetric aptasensor transduced by HCR-facilitated catalysis of AuNPs nanozyme for saxitoxin detection. Reprinted with permission from reference [96]. (F) Kanamycin detection based on the etching of Au@Ag nanostars by DNA/Ni-Fe LDO FNW. Reprinted with permission from reference [97]. 
Recently, Li et al. [95] developed a colorimetric detection for saxitoxin based on a terminalfixed aptamer with enhanced peroxidase-like activity of AuNPs by ssDNA (Figure 3D). A terminal-fixed aptamer was engineered by terminal hybridization (Figure $3 \mathrm{D}(\mathrm{a})$ ), which was verified as having 145 -fold enhancement of binding affinity to saxitoxin compared with the original aptamers. Then, terminal-fixed aptamers were hybridized with a complementary DNA (cDNA) to form terminal-fixed aptamer-cDNA complexes, which could not adsorb onto the surface of AuNPs. In the presence of saxitoxin, the cDNA was released from the terminal-fixed aptamer due to the specific binding between terminal-fixed aptamer and saxitoxin, followed by adsorption onto the surface of AuNPs and enhancement of the peroxidase-like activity of AuNPs. Based on this principle, the colorimetric aptasensor was developed with a LOD of $142.3 \mathrm{pM}$, and recoveries of $98.21-114.1 \%$ in seawater and scallop samples were achieved. In order to improve the sensitivity for saxitoxin detection, HCR and AuNP nanozymes were integrated into one aptasensor developed by the same group [96]. As shown in Figure 3E, cDNA-modified magnetic bead (MB) was hybridized with saxitoxin aptamers (M-30f) to form MB-cDNA-aptamer complexes. In the presence of saxitoxin, aptamers preferred to bind with saxitoxin and released from cDNA-MB. Then, the aptamer-saxitoxin complexes in the supernatant were collected through magnetic separation, serving as a trigger for the HCR to obtain long dsDNA products with a 10-base sticky fragment. With the addition of AuNPs, long dsDNA products adsorbed onto the surface of AuNPs via the 10-base sticky fragment, restricted a certain amount of AuNPs in the limited space, and increased the affinity of TMB to the dense AuNP nanozymes, resulting in the enhancement of the peroxidase-like activity of AuNPs. Without saxitoxin, the supernatant did not contain aptamers after magnetic separation, which hindered the HCR process and could not enhance the catalytic activity of AuNPs. Under optimum conditions, the AuNP-nanozyme-based aptasensor achieved a LOD of $42.46 \mathrm{pM}$ with a linear detection range of 78.13-2500 pM.

Recently, an ultrasensitive quad-amplification strategy for the detection of kanamycin was developed based on three-dimensional DNA/nickel-iron ( $\mathrm{Ni}-\mathrm{Fe}$ ) layered double oxide (LDO) frame network-induced "cusp-exposure" of Au@Ag nanostars [97]. As shown in Figure $3 \mathrm{~F}$, in the presence of kanamycin, the trigger was released from the aptamers due to the specific binding between kanamycin and aptamer, followed by catalytic hairpin assembly (CHA) and HCR to produce four-way DNA nanostructures. Then, the four-way DNA nanostructures were connected with Ni-Fe LDO to form a DNA/Ni-Fe LDO frame network via DNA hybridization. After magnetic separation, the separated DNA/Ni-Fe LDO frame network demonstrated strong peroxidase-like activity to catalyze TMB to produce $\mathrm{TMB}^{2+}$, which etched Ag onto the surface of Au@Ag nanostars and resulted in a red shift of the absorbance peak. By measuring the red shift value, this sensor achieved an ultralow LOD of $3 \mathrm{aM}$ and could detect $0.026 \mathrm{fM}$ kanamycin in milk. Table 2 summarizes the nanozyme-based aptasensors based on the enhancement of nanozyme activity by ssDNA.

Up to now, few studies have reported that food components enhanced nanozyme activity. Thus, aptasensors based on the enhancement of nanozyme activity by ssDNA demonstrated more reliable results in comparison with aptasensors based on the inhibition of nanozyme activity by ssDNA. However, the former had a lower signal-to-noise ratio than that of the latter, indicating lower sensitivity of the aptasensors based on the enhancement of nanozyme activity by ssDNA. 
Table 2. Nanozyme-based aptasensors based on the enhancement of nanozyme activity by ssDNA.

\begin{tabular}{|c|c|c|c|c|c|c|c|c|}
\hline S. No. & Contaminants & Nanozymes & Substrates & $\begin{array}{c}\text { Nanozyme Reaction condition } \\
\text { (Buffer, Temperature, } \\
\text { Reaction Time) }\end{array}$ & Sensitivity & Sample Matrix & Linear Range & References \\
\hline 1 & Kanamycin & $\begin{array}{c}\mathrm{BNQDs} / \mathrm{CeO}_{2} \\
\text { nanorods }\end{array}$ & $\mathrm{TMB} / \mathrm{H}_{2} \mathrm{O}_{2}$ & $\begin{array}{l}0.2 \mathrm{M} \text { acetate buffer }(\mathrm{pH} 4.0), \\
30^{\circ} \mathrm{C}, 10 \mathrm{~min}\end{array}$ & $4.6 \mathrm{pM}$ & $\begin{array}{l}\text { Swine urine, milk, } \\
\text { and wastewater }\end{array}$ & 0.01 to $100 \mathrm{nM}$ & [56] \\
\hline 2 & Tetracycline & AuNCs & $\mathrm{TMB} / \mathrm{H}_{2} \mathrm{O}_{2}$ & $\begin{array}{c}0.2 \mathrm{M} \mathrm{NaAc}-\mathrm{HAc} \text { buffer } \\
\text { (pH 3.8), room temperature, } \\
90 \mathrm{~min}\end{array}$ & $\begin{array}{c}46 \mathrm{nM} \text { (spec- } \\
\text { trophotometer), } \\
0.5 \mu \mathrm{M} \text { (naked-eye } \\
\text { detection) }\end{array}$ & Milk & 1 to $16 \mu \mathrm{M}$ & [85] \\
\hline 3 & Kanamycin & $\begin{array}{c}\text { Layered } \mathrm{WS}_{2} \\
\text { nanosheets }\end{array}$ & $\mathrm{TMB} / \mathrm{H}_{2} \mathrm{O}_{2}$ & $\begin{array}{c}20 \mathrm{mM} \mathrm{NaAc} \mathrm{buffer}(\mathrm{pH} \mathrm{4.0)},-, \\
50 \mathrm{~s}\end{array}$ & $0.06 \mu \mathrm{M}$ & $\begin{array}{l}\text { Milk, honey, and } \\
\text { pork }\end{array}$ & 0.1 to $0.5 \mu \mathrm{M}$ & [57] \\
\hline 4 & Sulfadimethoxine & $\begin{array}{c}\mathrm{Cu}(\mathrm{HBTC})- \\
1 / \mathrm{Fe}_{3} \mathrm{O}_{4}- \\
\text { AuNPs nanosheets }\end{array}$ & $\mathrm{TMB} / \mathrm{H}_{2} \mathrm{O}_{2}$ & $\begin{array}{l}0.2 \mathrm{M} \text { acetate buffer }(\mathrm{pH} 4.0) \\
\text { room temperature, } 3 \mathrm{~min}\end{array}$ & $1.70 \mu \mathrm{g} / \mathrm{L}$ & Tap water & $\begin{array}{c}3.57 \text { to } \\
357.14 \mu \mathrm{g} / \mathrm{L}\end{array}$ & [86] \\
\hline 5 & Cocaine & $\begin{array}{l}\text { Hemin- } \\
\text { functionalized } \\
\text { graphene } \\
\text { nanosheets }\end{array}$ & $\mathrm{ABTS} / \mathrm{H}_{2} \mathrm{O}_{2}$ & $\begin{array}{l}50 \mathrm{mM} \mathrm{NaH}_{2} \mathrm{PO}_{4}(\mathrm{pH} 3.6),-, \\
\text { immediate detection }\end{array}$ & $230 \mu \mathrm{M}$ & - & 0.5 to $5 \mathrm{mM}$ & [87] \\
\hline 6 & Abrin & AuNPs & $\mathrm{TMB} / \mathrm{H}_{2} \mathrm{O}_{2}$ & $-, 25^{\circ} \mathrm{C}, 10 \mathrm{~min}$ & $0.05 \mathrm{nM}$ & Raw milk & 0.2 to $17.5 \mathrm{nM}$ & [88] \\
\hline 7 & Malachite green & $\begin{array}{c}\mathrm{Fe}_{3} \mathrm{O}_{4} \\
\text { nanoparticles }\end{array}$ & $\mathrm{TMB} / \mathrm{H}_{2} \mathrm{O}_{2}$ & $\begin{array}{c}20 \mathrm{mM} \mathrm{NaAc}-\mathrm{HAc}(\mathrm{pH} 4.0), \\
37^{\circ} \mathrm{C}, 10 \mathrm{~min}\end{array}$ & $16.7 \mu \mathrm{g} / \mathrm{kg}$ & Fish and water & 0.06 to $2.38 \mu \mathrm{M}$ & [89] \\
\hline 8 & S. pneumoniae & $\begin{array}{l}\text { Citric acid- } \\
\text { functionalized } \\
\text { silver/copper } \\
\text { nanoparticles }\end{array}$ & $\mathrm{TMB} / \mathrm{H}_{2} \mathrm{O}_{2}$ & $-, 37^{\circ} \mathrm{C}, 10 \mathrm{~min}$ & $65 \mathrm{CFU} / \mathrm{mL}$ & $\begin{array}{l}\text { Milk and fruit } \\
\text { juice }\end{array}$ & $\begin{array}{c}10^{2} \text { to } \\
10^{8} \mathrm{CFU} / \mathrm{mL}\end{array}$ & [90] \\
\hline \multirow[t]{2}{*}{9} & $\mathrm{Hg}(\mathrm{II})$ & \multirow[t]{2}{*}{$\begin{array}{l}\mathrm{Pg}-\mathrm{C}_{3} \mathrm{~N}_{4} \\
\text { nanosheets }\end{array}$} & \multirow[t]{2}{*}{$\mathrm{OPD} / \mathrm{H}_{2} \mathrm{O}_{2}$} & \multirow[t]{2}{*}{$\begin{array}{c}10 \mathrm{mM} \mathrm{NaAc}-\mathrm{HAc} \text { buffer } \\
(\mathrm{pH} 4.0), 35^{\circ} \mathrm{C}, 3 \mathrm{~min},\end{array}$} & $0.01 \mathrm{nM}$ & $\begin{array}{l}\text { Real Xiangjiang } \\
\text { River water from } \\
\text { Changsha and tap } \\
\text { water from } \\
\text { laboratory }\end{array}$ & 0.05 to $100 \mathrm{nM}$ & \multirow[t]{2}{*}{ [50] } \\
\hline & AFB1 & & & & $0.01 \mathrm{pg} / \mathrm{mL}$ & $\begin{array}{l}\text { Peanut, maize, } \\
\text { and wheat }\end{array}$ & 0.1 to $60 \mathrm{pg} / \mathrm{mL}$ & \\
\hline
\end{tabular}


Table 2. Cont.

\begin{tabular}{|c|c|c|c|c|c|c|c|c|}
\hline S. No. & Contaminants & Nanozymes & Substrates & $\begin{array}{c}\text { Nanozyme Reaction condition } \\
\text { (Buffer, Temperature, } \\
\text { Reaction Time) }\end{array}$ & Sensitivity & Sample Matrix & Linear Range & References \\
\hline 10 & Acetamiprid & Hemin-rGO & $\mathrm{TMB} / \mathrm{H}_{2} \mathrm{O}_{2}$ & $\begin{array}{c}25 \mathrm{mM} \text { PBS (pH 5.0), } 35^{\circ} \mathrm{C}, \\
10 \mathrm{~min}\end{array}$ & $40 \mathrm{nM}$ & Wastewater & 0.1 to $10 \mu \mathrm{M}$ & [91] \\
\hline 11 & Bisphenol A & Hemin-rGO & $\mathrm{TMB} / \mathrm{H}_{2} \mathrm{O}_{2}$ &,,--- & $2 \mathrm{nM}$ & Tap water & 5 to $100 \mathrm{nM}$ & [92] \\
\hline 12 & $\begin{array}{l}\mathrm{Hg}(\mathrm{II}) \\
\mathrm{Pb}(\mathrm{II})\end{array}$ & $\begin{array}{c}\text { Graphene } \\
\text { oxide-gold } \\
\text { nanohybrids }\end{array}$ & $\mathrm{TMB} / \mathrm{H}_{2} \mathrm{O}_{2}$ & $\begin{array}{l}33.3 \mathrm{mM} \text { sodium acetate buffer } \\
\text { (pH 4.3) },-,-\end{array}$ & $\begin{array}{l}300 \mathrm{nM} \\
500 \mathrm{nM}\end{array}$ & River water & 0 to $50 \mu \mathrm{M}$ & [93] \\
\hline 13 & Malachite green & AuNPs & $\mathrm{TMB} / \mathrm{H}_{2} \mathrm{O}_{2}$ & $\begin{array}{c}10 \mathrm{mM} \mathrm{NaAc-HAc}(\mathrm{pH} 4.0),-, \\
20 \mathrm{~min}\end{array}$ & $1.8 \mathrm{nM}$ & $\begin{array}{l}\text { Fresh water and } \\
\text { seawater }\end{array}$ & 10 to $500 \mathrm{nM}$ & [94] \\
\hline 14 & Saxitoxin & AuNPs & $\mathrm{TMB} / \mathrm{H}_{2} \mathrm{O}_{2}$ & Acetate acid (pH 4.0), -, 15 min. & $142.3 \mathrm{pM}$ & $\begin{array}{l}\text { Seawater and } \\
\text { scallop }\end{array}$ & 0.1457 to $37.30 \mathrm{nM}$ & [95] \\
\hline 15 & Saxitoxin & AuNPs & $\mathrm{TMB} / \mathrm{H}_{2} \mathrm{O}_{2}$ & Acetate acid ( $\mathrm{pH} 4.0),-, 25^{\circ} \mathrm{C}$ & $42.46 \mathrm{pM}$ & Scallop & 78.13 to $2500 \mathrm{pM}$ & [96] \\
\hline 16 & Kanamycin & Ni-Fe LDO & $\mathrm{TMB} / \mathrm{H}_{2} \mathrm{O}_{2}$ & $\begin{array}{l}0.1 \mathrm{M} \mathrm{NaAc}-\mathrm{HAc}(\mathrm{pH} 4.0),-, \\
5 \mathrm{~min}\end{array}$ & $3 \mathrm{aM}$ & Milk & $0.01 \mathrm{fM}$ to $0.1 \mathrm{nM}$ & [97] \\
\hline
\end{tabular}




\subsection{Nanozymes as Signal Tags}

Besides using aptamers to regulate nanozyme activity, another strategy is to apply nanozymes as tags, which aims to establish a proportional relationship between nanozymes and analyte concentrations. The sandwich-type model is one of the most popular approaches to construct highly-sensitive detection of macromolecules, which involves two different recognition molecules binding with target molecules. A colorimetric aptasensor was developed using aptamer immobilized onto a microplate as the capture probe and aptamer-modified $\mathrm{ZnFe}_{2} \mathrm{O}_{4} / \mathrm{rGO}$ nanozymes as a signal probe for the detection of $S$. typhimurium, and a LOD of $11 \mathrm{CFU} / \mathrm{mL}$ was achieved [98] (Figure 4A). Similar research was reported by Duan et al. [99] using aptamer-modified copper-based MOF (Cu-MOF) nanoparticles as signal probes for detecting E. coli. In another study, a vancomycin-modified microplate and aptamer-conjugated $\mathrm{Fe}_{3} \mathrm{O}_{4}$ nanoparticle clusters were used to recognize different sites of L. monocytogenes, with a LOD of $5.4 \times 10^{3} \mathrm{CFU} / \mathrm{mL}$ [100]. In order to improve sensitivity and shorten detection time, Liu et al. [101] utilized aptamer-modified $\mathrm{MB}$ as a capture probe to extract L. monocytogenes from matrix and lgY-antibody-conjugated silver nanoclusters as signal probes to catalyze the substrate OPD, which produced a red color. The method achieved a LOD of $10 \mathrm{CFU} / \mathrm{mL}$ without pre-enrichment. Then, the same group also designed another sensitive and reliable multicolorimetric assay for L. monocytogenes based on the oxidase-like activity of $\mathrm{MnO}_{2}$ and $\mathrm{TMB}^{2+}$ etching of gold nanorods (AuNRs) [102]. A sandwich-type model was formed between aptamer- $\mathrm{Fe}_{3} \mathrm{O}_{4}, L$. monocytogenes, and lgY-antibody-modified bovine serum albumin (BSA)- $\mathrm{MnO}_{2}$ nanozymes. Then, the TMB was catalyzed by $\lg \mathrm{Y}-\mathrm{BSA}-\mathrm{MnO}_{2}$ to produce $\mathrm{TMB}^{+}$that exhibited blue color. After adding $\mathrm{HCl}$, Au was oxidized to $\mathrm{Au}(\mathrm{I})$ and yellow $\mathrm{TMB}^{2+}$ was obtained, resulting in a decrease in the aspect ratios of AuNRs, which produced rich-colored optical signals (Figure 4B). Consequently, as little as $10 \mathrm{CFU} / \mathrm{mL}$ of L. monocytogenes was detected by the naked eye. Wang et al. [103] developed a similar sandwich-type model based on both aptamer-modified MB and Cu-MOF nanozymes for detecting S. aureus by measuring residual $\mathrm{Cu}-\mathrm{MOF}$ nanozymes in the supernatant. The oxidation product of TMB (oxTMB) was inversely proportional to the concentration of $S$. aureus. A LOD of $20 \mathrm{CFU} / \mathrm{mL}$ was achieved by this method based on $S / N=3$. When using AuNP nanozymes to replace $\mathrm{Cu}-\mathrm{MOF}$ nanozymes in the sandwich-type model, Yao et al. [104] found that modifying S. aureus aptamer on the surface of AuNPs resulted in the inhibition of the peroxidaselike activity of AuNPs. Thus, etching solution $\left(1 \mu \mathrm{M} \mathrm{H}_{2} \mathrm{O}_{2}\right.$ and $\left.1 \mu \mathrm{M} \mathrm{H}_{3} \mathrm{PO}_{4}\right)$ was used to enhance the peroxidase-like activity of residual apt-AuNPs in the supernatant after magnetic separation. Finally, the proposed method had a LOD of $10 \mathrm{CFU} / \mathrm{mL}$ under optimum conditions.

However, some small molecules have limited binding sites, and it is difficult to find two different recognition molecules to recognize them for constructing biosensors [109]. Thus, an indirect competitive enzyme-linked aptamer assay (ELAA) was developed for detecting tetracycline residues based on the peroxidase-like activity of AuNPs and one aptamer. The study achieved a LOD of $2.7 \mathrm{nM}$ [110]. The tetracycline with a known concentration immobilized on the microplate competed with target tetracycline in honey to bind aptamer-modified AuNPs. Large amounts of tetracycline in honey resulted in small amounts of aptamer-AuNPs binding with the tetracycline immobilized on the microplate, which produced a light blue color in the presence of TMB- $\mathrm{H}_{2} \mathrm{O}_{2}$. Contrarily, a small amount of tetracycline in honey produced a dark blue color. 

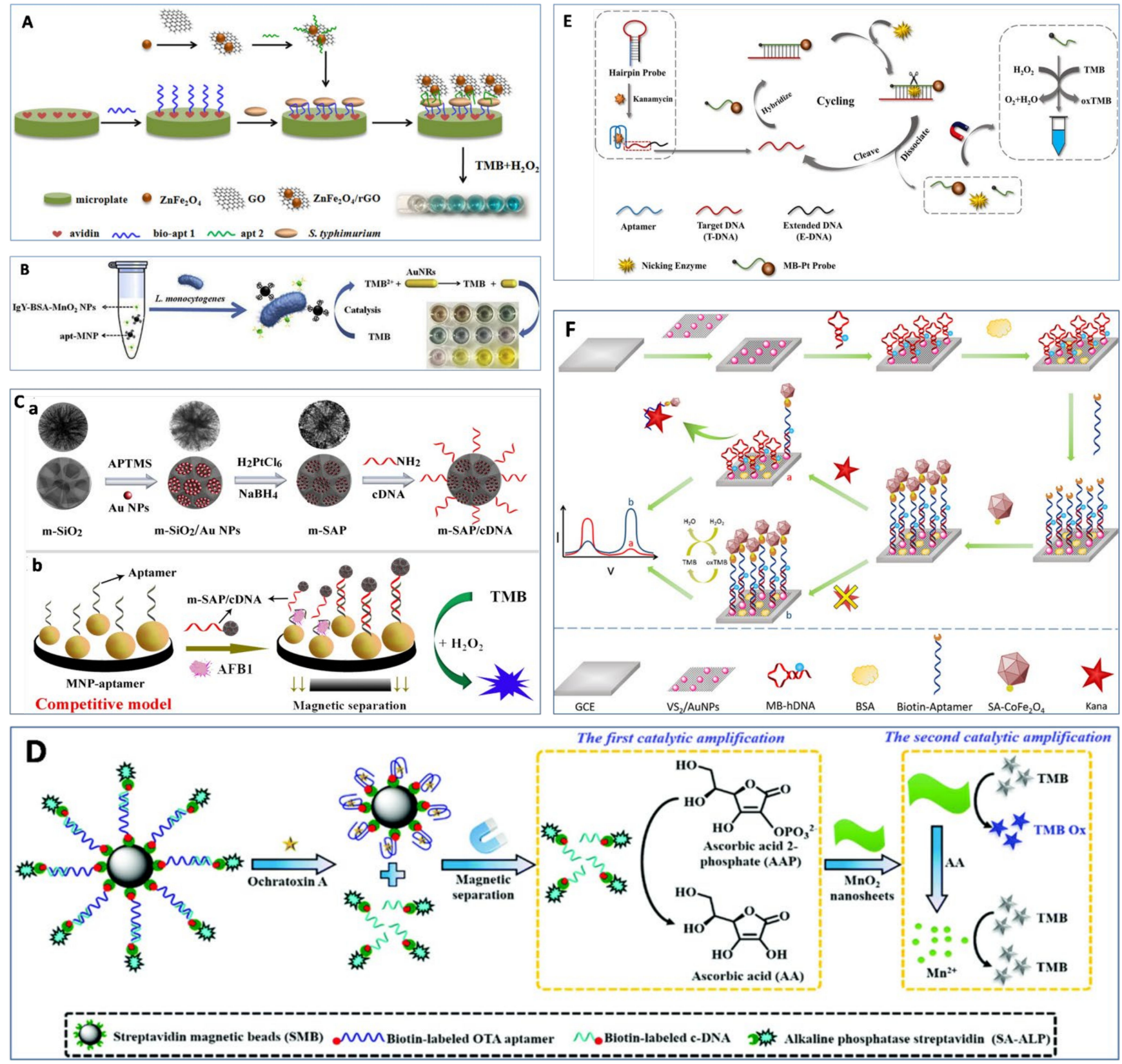

Figure 4. Examples of aptasensor based on nanozymes as signal tags. (A) Colorimetric aptasensor for $S$. typhimurium detection using the peroxidase-like activity of $\mathrm{ZnFe}_{2} \mathrm{O}_{4}$-reduced graphene oxide nanostructures [98]. (B) A multicolorimetric assay for L. monocytogenes detection based on the etching of gold nanorods [102]. (C) A nanozyme-based competitive colorimetric aptasensor for AFB1 detection [105]. (a) The synthesis process for m-SAP/cDNA, (b) The principle of nanozyme-based competitive colorimetric aptasensor for AFB1 detection. (D) A nanozyme-based cascade colorimetric aptasensor for OTA detection [106]. (E) A colorimetric bioassay for detecting kanamycin based on aptamer biorecognition-triggered hairpin switch and nicking-enzyme-assisted signal amplification [107]. (F) Ratiometric dual signal-enhancing-based electrochemical biosensor for ultrasensitive kanamycin detection [108]. Copyright 2020 American Chemical Society. 
In addition, aptamer and its cDNA are usually used to design various detection methods for food contaminants. Wu et al. [105] developed a nanozyme-based competitive colorimetric aptasensor for AFB1 detection. As shown in Figure 4C, the aptasensor consisted of aptamer-modified $\mathrm{Fe}_{3} \mathrm{O}_{4}$ magnetic nanoparticles (MNP) as capture probes and cDNA-modified mesoporous $\mathrm{SiO}_{2} / \mathrm{Au}-\mathrm{Pt}(\mathrm{m}-\mathrm{SAP}$ ) nanozymes as signal probes. The presence of AFB1 induced the dissociation of cDNA-modified m-SAP nanozyme from MNP, resulting in low absorbance at $650 \mathrm{~nm}$ of nanozymes. This aptasensor demonstrated the lowest LOD of $5 \mathrm{nM}$ due to the high peroxidase-like activity of m-SAP. Good selectivity was also confirmed in that the signal for ABF1 was 60 times higher than those of other six mytoxins. In addition, Zhu et al. [111] developed a self-powered photoelectrochemical aptasensor based on the peroxidase-like activity of PtNi nanowires and with benzenering-doped g- $\mathrm{C}_{3} \mathrm{~N}_{4}$ (BR-CN) as the photoactive material for detecting chloramphenicol. cDNA was first immobilized on a BR-CN-functionalized fluorine-doped tin oxide (FTO) electrode. Then, the biotinylated aptamer (bio-aptamer) was hybridized with cDNA to form biotin-modified dsDNA on the surface of BR-CN/FTO, followed by the addition of streptavidin (SA)-modified PtNi nanozyme to form PtNi-nanozyme-modified dsDNA. PtNi nanozyme catalyzed the oxidation of 4-chloro-1-naphthol (4-CN) by $\mathrm{H}_{2} \mathrm{O}_{2}$ to produce insoluble benzo-4-chlorohexadienone (4-CD) on the electrode surface, resulting in a remarkable decrease in the photocurrent. Contrarily, bio-aptamer was released from the electrode surface in the presence of chloramphenicol. Thus, a lower amount of PtNi nanozyme was captured, resulting in a decrease in catalytic precipitation (4-CD) and an increase in photocurrent signal. By measuring the change in photocurrent intensity, the LOD of $26 \mathrm{fM}$ was obtained with a wide linear range of $0.1 \mathrm{pM}-100 \mathrm{nM}$.

Wang et al. [112] developed a simple colorimetric aptasensor for OTA using $\mathrm{Au} \mathrm{Fe}_{3} \mathrm{O}_{4}$ nanoparticles as a signal indicator and magnetic separator with a LOD of $30 \mathrm{pg} / \mathrm{mL}$. The amino-modified aptamer was immobilized on the surface of glass beads to hybridize with cDNA-modified $\mathrm{Au} @ \mathrm{Fe}_{3} \mathrm{O}_{4}$. After adding OTA, the aptamers preferred to bind to the OTA, resulting in the dissociation of cDNA-Au $@ \mathrm{Fe}_{3} \mathrm{O}_{4}$ from the surface of glass. The released $\mathrm{Au} @ \mathrm{Fe}_{3} \mathrm{O}_{4}$ nanoparticles were collected by magnetic separation, which catalyzed TMB to produce a blue color in the presence of $\mathrm{H}_{2} \mathrm{O}_{2}$. Similar strategies were also reported to detect AFB1 [113], Cd(II) [114], and chlorpyrifos [115]. On the basis of the methods above, Tian et al. [106] incorporated a cascade reaction (alkaline phosphatase and $\mathrm{MnO}_{2}$ nanozymes) into aptasensors for achieving a $0.069 \mathrm{nM}$ LOD of OTA detection (Figure 4D). The ascorbic acid-2-phosphate was catalyzed into ascorbic acid by the released cDNA-modified alkaline phosphatase. Subsequently, the generated ascorbic acid dissolved $\mathrm{MnO}_{2}$ nanozymes to generate $\mathrm{Mn}^{2+}$ ions, which was not able to catalyze TMB to produce a blue color. Thus, increasing the amount of OTA resulted in the change of color from blue to colorless. On the other hand, Tao et al. [116] utilized the dissociation of cDNA from aptamer-modified MNP by the induction of $\mathrm{Pb}$ (II) to inhibit the peroxidase-like activity of graphene $/ \mathrm{Fe}_{3} \mathrm{O}_{4}-\mathrm{Au}$. The proposed method achieved a LOD of $0.63 \mu \mathrm{M}$ with the linear range of 1-300 $\mu \mathrm{M}$. Moreover, Wang et al. [117] developed an ultrasensitive electrochemical aptasensor for detecting $\mathrm{Hg}^{2+}$ based on gold-palladium-modified zirconium metal-organic framework (AuPd@UiO67) nanozyme and T-Hg(II)-T structure, with a LOD of $0.16 \mathrm{nM}$. Gold-modified thiol graphene (Au@HS-rGO) was immobilized on the electrode, followed by the modification of HS-aptamer 1 on the electrode via Au-S bond. Then, different concentrations of $\mathrm{Hg}^{2+}$ were embellished on the aptamer 1. Finally, aptamer-2-functionalized AuPd@UiO-67 was immobilized on the electrode via $\mathrm{T}-\mathrm{Hg}$ (II)-T structure and DNA hybridization. The current signal could be obtained via the catalytic activity of AuPd@UiO-67 nanozyme toward $\mathrm{H}_{2} \mathrm{O}_{2}$. With the increase in $\mathrm{Hg}^{2+}$ concentration, the current signal was enhanced.

Recently, an ultrasensitive colorimetric sensor was developed for detecting kanamycin based on an aptamer biorecognition-triggered hairpin switch and nicking-enzyme-assisted signal amplification, which obtained a LOD of $0.2 \mathrm{pg} / \mathrm{mL}$ [107]. As shown in Figure 4E, the hairpin probe contained three parts: kanamycin aptamer, target DNA (T-DNA) located in the hairpin ring, and extended DNA (E-DNA) as an auxiliary stabilizer to the hairpin 
structure. In the presence of kanamycin, the formed hairpin probe was broken due to the specific binding between aptamer and kanamycin, which prompted the hybridization between the T-DNA and the signal probe. It should be noted that both ends of the signal probe were modified with $\mathrm{MB}$ and Pt nanozyme. With the help of nicking enzyme, the signal probe was cleaved into two parts (magnetic bead signal probe and Pt nanozyme signal probe). After magnetic separation, the supernatant containing numerous Pt nanozymes was used to catalyze the oxidation of TMB by $\mathrm{H}_{2} \mathrm{O}_{2}$. Moreover, Tian et al. [108] reported a ratiometric dual signal-enhancing-based electrochemical aptasensor for ultrasensitive detection of kanamycin with a LOD of $0.5 \mathrm{pM}$ (Figure $4 \mathrm{~F}$ ). The $\mathrm{VS}_{2} /$ AuNPs nanocomposites were modified on the surface of a glassy carbon electrode (GCE), which remarkably accelerated the interface electron transfer. Then, MB-hairpin DNA-SH was coupled with $\mathrm{VS}_{2}$ / AuNPs/GCE via the Au-S bond, followed by hybridization with the biotin-aptamer to form the double-stranded structure on the electrode. Subsequently, $\mathrm{CoFe}_{2} \mathrm{O}_{4}$ nanozymes conjugated streptavidin bound to biotin-aptamer-catalyzed TMB to produce a strong electronic signal at $0.23 \mathrm{~V}$. In the presence of kanamycin, the aptamer- $\mathrm{CoFe}_{2} \mathrm{O}_{4}$ nanozyme dissociated from the electrode surface, leading to a re-formation of the hairpin DNA. Then, the re-formed hairpin DNA brought MB close to the electrode surface. The electronic signal produced by TMB decreased at $0.23 \mathrm{~V}$, and $\mathrm{MB}$ increased greatly at $-0.31 \mathrm{~V}$. By measuring the change in the peak current ratio $\left(\mathrm{I}_{\mathrm{MB}} / \mathrm{I}_{\mathrm{TMB}}\right)$, this electrochemical aptasensor demonstrated a linear dynamic detection ranging from $1 \mathrm{pM}$ to $1 \mu \mathrm{M}$, with a LOD of $0.5 \mathrm{pM}$. The aptasensors based on nanozymes as signal tags and other methods are presented in Table 3.

Using nanozymes as signal tags in the detection system, especially ELISA, is the typical method used for the quantitative detection of food contaminants and holds great potential to be extended to in-field applications. Simplifying the steps of these aptasensors would accelerate the development of commercialized nanozyme-based aptasensors and should be addressed in future research.

\subsection{Other Methods Based on Nanozymes and Aptamers}

Besides aptamers, $S$. aureus have also been found to inhibit the activity of nanozymes. Zhang et al. [119] developed one-step colorimetric detection of S. aureus based on targetinduced shielding against the peroxidase-like activity of aptamer-modified $\mathrm{Fe}_{3} \mathrm{O}_{4}-\mathrm{Au}$ nanocomposites. The color change from dark blue to light blue was proportional to the concentration of $S$. aureus. This colorimetric method was able to detect $10 \mathrm{CFU} / \mathrm{mL}$ of $S$. aures by the naked eye in $12 \mathrm{~min}$. The feasibility of this method in five real samples (tap water, Nanhu Lake water, industrial wastewater, urine sample, and milk) was carried out with recoveries between $86.5 \%$ and $122.3 \%$. However, a different phenomenon occurred between $S$. typhimurium and gold nanoclusters (AuNCs). Micro-sized S. typhimurium captured by aptamer-modified BSA-AuNCs adsorbed more TMB, promoting the affinity between TMB and aptamer-modified BSA-AuNCs. Based on this principle, the developed colorimetric sensor detected $S$. typhimurium with a LOD of 1 CFU/mL [120]. This proposed method was also verified by successful detection of $S$. typhimurium in egg samples, with recoveries between $92.4 \%$ and $110 \%$. 
Table 3. Nanozyme-based aptasensors based on nanozyme as signal tag and other methods.

\begin{tabular}{|c|c|c|c|c|c|c|c|c|}
\hline S. No. & Contaminants & Nanozymes & Substrates & $\begin{array}{c}\text { Nanozyme Reaction } \\
\text { Condition (Buffer, } \\
\text { Temperature, Reaction Time) }\end{array}$ & Sensitivity & Sample Matrix & Linear Range & References \\
\hline 1 & S. typhimurium & $\begin{array}{l}\mathrm{ZnFe}_{2} \mathrm{O}_{4} \text {-reduced } \\
\text { graphene oxide } \\
\text { nanostructures }\end{array}$ & $\mathrm{TMB} / \mathrm{H}_{2} \mathrm{O}_{2}$ & $\mathrm{NaAc}(\mathrm{pH} 3.5),-, 20 \mathrm{~min}$ & $11 \mathrm{CFU} / \mathrm{mL}$ & Milk & $\begin{array}{l}11 \text { to } 1.10 \times 10^{5} \\
\quad \mathrm{CFU} / \mathrm{mL}\end{array}$ & [98] \\
\hline 2 & E. coli & $\mathrm{Cu}-\mathrm{MOF}$ & $\mathrm{TMB} / \mathrm{H}_{2} \mathrm{O}_{2}$ & $0.2 \mathrm{M}$ acetate $(\mathrm{pH} 4.0),-, 10 \mathrm{~min}$ & $2 \mathrm{CFU} / \mathrm{mL}$ & Milk & $\begin{array}{l}16 \text { to } 1.6 \times 10^{6} \\
\mathrm{CFU} / \mathrm{mL}\end{array}$ & [99] \\
\hline 3 & L. monocytogenes & $\begin{array}{c}\mathrm{Fe}_{3} \mathrm{O}_{4} \\
\text { nanoparticle } \\
\text { cluster }\end{array}$ & $\mathrm{TMB} / \mathrm{H}_{2} \mathrm{O}_{2}$ &,,--- & $\begin{array}{l}5.4 \times 10^{3} \\
\mathrm{CFU} / \mathrm{mL}\end{array}$ & Milk & $\begin{array}{l}5.4 \times 10^{3} \text { to } \\
10^{8} \mathrm{CFU} / \mathrm{mL}\end{array}$ & [100] \\
\hline 4 & L. monocytogenes & $\begin{array}{c}\text { Silver } \\
\text { nanoclusters }\end{array}$ & OPD & -, room temperature, $3 \mathrm{~min}$ & $10 \mathrm{CFU} / \mathrm{mL}$ & Pork & 10 to $10^{6} \mathrm{CFU} / \mathrm{mL}$ & [101] \\
\hline 5 & L. monocytogenes & $\mathrm{MnO}_{2}$ & TMB &,,--- & $10 \mathrm{CFU} / \mathrm{mL}$ & Pork & 10 to $10^{6} \mathrm{CFU} / \mathrm{mL}$ & [102] \\
\hline 6 & S. aureus & $\mathrm{Cu}-\mathrm{MOF}$ & $\mathrm{TMB} / \mathrm{H}_{2} \mathrm{O}_{2}$ & $-, 45^{\circ} \mathrm{C}, 10 \mathrm{~min}$ & $20 \mathrm{CFU} / \mathrm{mL}$ & Milk & $\begin{array}{c}50 \text { to } \\
10,000 \mathrm{CFU} / \mathrm{mL}\end{array}$ & [103] \\
\hline 7 & S. aureus & AuNPs & $\mathrm{TMB} / \mathrm{H}_{2} \mathrm{O}_{2}$ &,,$-- 5 \mathrm{~min}$ & $10 \mathrm{CFU} / \mathrm{mL}$ & Pork and milk & 10 to $10^{6} \mathrm{CFU} / \mathrm{mL}$ & {$[104]$} \\
\hline 8 & Tetracycline & AuNPs & $\mathrm{TMB} / \mathrm{H}_{2} \mathrm{O}_{2}$ & $\begin{array}{c}\text { Buffer }(0.08 \mathrm{M} \\
\mathrm{Na}_{2} \mathrm{HPO}_{4} \cdot 12 \mathrm{H}_{2} \mathrm{O}, 0.1 \mathrm{M} \text { citric } \\
\text { acid }),-, 15 \mathrm{~min}\end{array}$ & $2.7 \mathrm{pg} / \mathrm{mL}$ & Honey & 0.01 to $10 \mathrm{ng} / \mathrm{mL}$ & [110] \\
\hline 9 & AFB1 & $\begin{array}{l}\text { Mesoporous } \\
\mathrm{SiO}_{2} / \mathrm{Au}-\mathrm{Pt}\end{array}$ & $\mathrm{TMB} / \mathrm{H}_{2} \mathrm{O}_{2}$ & -, room temperature, $10 \mathrm{~min}$ & $5 \mathrm{pg} / \mathrm{mL}$ & Peanut & $\begin{array}{c}0.01 \text { to } \\
1000 \mathrm{ng} / \mathrm{mL}\end{array}$ & [105] \\
\hline 10 & Chloramphenicol & PtNi nanowires & $\begin{array}{c}\text { 4-chloro-1- } \\
\text { naphthol } / \mathrm{H}_{2} \mathrm{O}_{2}\end{array}$ & -, room temperature, $20 \mathrm{~min}$ & $26 \mathrm{fM}$ & $\begin{array}{l}\text { Pig urine, river } \\
\text { water, and milk }\end{array}$ & $0.1 \mathrm{pM}$ to $100 \mathrm{nM}$ & [111] \\
\hline 11 & OTA & $\begin{array}{c}\mathrm{Au} @ \mathrm{Fe}_{3} \mathrm{O}_{4} \\
\text { nanoparticles }\end{array}$ & $\mathrm{TMB} / \mathrm{H}_{2} \mathrm{O}_{2}$ & $\begin{array}{l}0.2 \mathrm{M} \text { acetate buffer solution } \\
(\mathrm{pH} 4.0), 40^{\circ} \mathrm{C}, 15 \mathrm{~min}\end{array}$ & $30 \mathrm{pg} / \mathrm{mL}$ & Cereal & 0.5 to $100 \mathrm{ng} / \mathrm{mL}$ & [112] \\
\hline 12 & AFB1 & AuNPs & $\mathrm{TMB} / \mathrm{H}_{2} \mathrm{O}_{2}$ & $\begin{array}{l}0.2 \mathrm{M} \text { acetate buffer solution, } \\
40^{\circ} \mathrm{C}, 20 \mathrm{~min}\end{array}$ & $0.43 \mathrm{pg} / \mathrm{mL}$ & Corn & 5 to $200 \mathrm{ng} / \mathrm{mL}$ & [113] \\
\hline 13 & $\mathrm{Cd}(\mathrm{II})$ & $\begin{array}{c}\mathrm{Au}-\mathrm{MoS}_{2} \\
\text { nanocomposites }\end{array}$ & $\mathrm{TMB} / \mathrm{H}_{2} \mathrm{O}_{2}$ & - , room temperature, $5 \mathrm{~min}$ & $0.7 \mathrm{ng} / \mathrm{mL}$ & White wine & 1 to $500 \mathrm{ng} / \mathrm{mL}$ & [114] \\
\hline
\end{tabular}


Table 3. Cont.

\begin{tabular}{|c|c|c|c|c|c|c|c|c|}
\hline S. No. & Contaminants & Nanozymes & Substrates & $\begin{array}{c}\text { Nanozyme Reaction } \\
\text { Condition (Buffer, } \\
\text { Temperature, Reaction Time) }\end{array}$ & Sensitivity & Sample Matrix & Linear Range & References \\
\hline 14 & Chlorpyrifos & $\mathrm{Cu}-\mathrm{MOF}$ & $\mathrm{TMB} / \mathrm{H}_{2} \mathrm{O}_{2}$ &,$- 40^{\circ} \mathrm{C}$ water bath, $15 \mathrm{~min}$ & $4.4 \mathrm{ng} / \mathrm{mL}$ & $\begin{array}{l}\text { Winter jujube, } \\
\text { apple, cabbage, } \\
\text { and cucumber }\end{array}$ & 0 to $1250 \mathrm{ng} / \mathrm{mL}$ & [115] \\
\hline 15 & OTA & $\mathrm{MnO}_{2}$ nanosheets & TMB & $\begin{array}{l}0.2 \mathrm{M} \mathrm{NaAc}-\mathrm{HAc}(\mathrm{pH} 4.5) \\
\text { room temperature, } 5 \mathrm{~min}\end{array}$ & $0.069 \mathrm{nM}$ & Grape juice & 1.25 to $250 \mathrm{nM}$ & [106] \\
\hline 16 & $\mathrm{~Pb}(\mathrm{II})$ & $\begin{array}{c}\text { Graphene } / \mathrm{Fe}_{3} \mathrm{O}_{4}- \\
\mathrm{Au} \\
\text { nanoparticles }\end{array}$ & $\mathrm{TMB} / \mathrm{H}_{2} \mathrm{O}_{2}$ & -, room temperature, $5 \mathrm{~min}$ & $0.63 \mathrm{ng} / \mathrm{mL}$ & Tap water & 1 to $300 \mathrm{ng} / \mathrm{mL}$ & [116] \\
\hline 17 & $\mathrm{Hg}(\mathrm{II})$ & $\begin{array}{c}\text { AuPd@UiO-67 } \\
\text { nanomaterial }\end{array}$ & $\mathrm{H}_{2} \mathrm{O}_{2}$ &,,--- & $0.16 \mathrm{nM}$ & $\begin{array}{l}\text { Tap water and } \\
\text { lake water }\end{array}$ & 1.0 to $10^{3} \mathrm{nM}$ & [117] \\
\hline 18 & Kanamycin & Pt nanoparticles & $\mathrm{TMB} / \mathrm{H}_{2} \mathrm{O}_{2}$ & $-, 45^{\circ} \mathrm{C}, 10 \mathrm{~min}$ & $0.2 \mathrm{pg} / \mathrm{mL}$ & Milk & $\begin{array}{c}0.5 \text { to } 2 \times 10^{5} \\
\mathrm{pg} / \mathrm{mL}\end{array}$ & [107] \\
\hline 19 & Kanamycin & $\begin{array}{c}\mathrm{CoFe}_{2} \mathrm{O}_{4} \\
\text { nanoparticles }\end{array}$ & $\mathrm{TMB} / \mathrm{H}_{2} \mathrm{O}_{2}$ & $0.01 \mathrm{M}$ PBS, -, - & $0.5 \mathrm{pM}$ & Milk & $1 \mathrm{pM}$ to $1 \mu \mathrm{M}$ & [108] \\
\hline 21 & S. aureus & $\begin{array}{c}\mathrm{Fe}_{3} \mathrm{O}_{4}-\mathrm{Au} \\
\text { nanoparticles }\end{array}$ & $\mathrm{TMB} / \mathrm{H}_{2} \mathrm{O}_{2}$ & $\begin{array}{l}0.2 \mathrm{M} \text { acetate acid -sodium } \\
\text { acetate buffer }(\mathrm{pH} 4.0), \text { room } \\
\text { temperature, } 2 \mathrm{~min}\end{array}$ & $\begin{array}{l}10 \mathrm{CFU} / \mathrm{mL} \text { by } \\
\text { eye, } 26 \mathrm{CFU} / \mathrm{mL} \\
\text { by spectropho- } \\
\text { tometer }\end{array}$ & $\begin{array}{l}\text { Tap water, Nanhu } \\
\text { Lake water, } \\
\text { industrial } \\
\text { wastewater, urine } \\
\text { sample, and milk }\end{array}$ & 10 to $10^{6} \mathrm{CFU} / \mathrm{mL}$ & [119] \\
\hline 22 & S. typhimurium & AuNCs & $\mathrm{TMB} / \mathrm{H}_{2} \mathrm{O}_{2}$ & $10 \mathrm{mM}$ PBS (pH 5.5), -, $3 \mathrm{~min}$ & $1 \mathrm{CFU} / \mathrm{mL}$ & $\begin{array}{c}\text { Eggshell and egg } \\
\text { white }\end{array}$ & 10 to $10^{6} \mathrm{CFU} / \mathrm{mL}$ & [120] \\
\hline
\end{tabular}




\section{Conclusions and Perspective}

Nanozyme-based aptasensors are intensively studied in food safety areas, as is evidenced by a dramatic increase in the number of research articles in the past few years. Due to the extraordinary properties of nanozymes and aptamer, the integration of various nanozymes into aptasensors has significantly improved analytical performance, including sensitivity, selectively, and reproducibility [121]. Compared with conventional ELISA, nanozyme-based aptasensors had some advantages, including high sensitivity and stability and low cost. Thus, nanozyme-based aptasensors are promising alternative tools for rapid detection of food contaminants. Compared with nanozymes serving as signal labels, nanozyme-based aptasensors based on the regulation of nanozyme activity by ssDNA have attracted more attention due to their simplicity, rapidity, and universality. Thus, in this review, the key factors affecting the regulation of nanozyme activity by ssDNA were discussed in detail.

Although a great deal of progress has been made in developing nanozyme-based aptasensors over the past 20 years, many challenges and obstacles still need to be overcome for real-world applications and commercialization. Although various factors were reported to modulate nanozyme activity, the nanozyme activity was still not as good as that of natural nanozymes. Thus, nanozymes with high catalytic activity need to be explored since high catalytic activity would bring high sensitivity of biosensors. Exploiting hybrid nanocomposite enzymes may be a simple strategy for obtaining nanozymes with high catalytic activity. In addition, the mechanism of regulation of nanozyme activity by ssDNA needs to be investigated in depth, because there are still some contradicting points about the relationship between ssDNA and nanozymes. A thorough understanding of the ssDNA regulation mechanism of nanozyme activity would help us to precisely tailor nanozyme activity and further apply it to construct DNA-controllable nanozyme sensing systems. Computer simulation methods may be a good tool to study the regulation mechanism. Finally, as food matrixes are usually complicated, complex sample pretreatment is required to reduce their influence on nanozyme activity to obtain a reliable and sensitive nanozymebased aptasensor. Thus, high-performance detection with less sample pretreatment would be welcomed in future studies.

Author Contributions: Conceptualization, L.W.; investigation, H.Z. and H.H.; writing-original draft preparation, L.W.; writing—review and editing, L.W. and Q.W.; supervision, Q.W. and X.C. All authors have read and agreed to the published version of the manuscript.

Funding: This research was funded by Sichuan Science and Technology Program (2020YFN0041, 2020YFN0151, 2020YFN0153) and the Open Project Program of the State Key Laboratory of Food Science and Technology, Nanchang University (No. SKLF-KF-202025).

Institutional Review Board Statement: Not applicable.

Informed Consent Statement: Not applicable.

Data Availability Statement: The study did not report any data.

Conflicts of Interest: The authors declare no conflict of interest.

\section{Abbreviations}

ELISA: enzyme-linked immunosorbent assay; ICP-MS, inductively coupled plasma mass spectrometry; HRP, horseradish peroxidase; MOF, metal-organic framework; SELEX, systematic evolution of ligands by exponential enrichment; ssDNA, single-stranded DNA; $g-C_{3} \mathrm{~N}_{4} @ \mathrm{Cu}_{2} \mathrm{O}$, graphitic carbon nitride@ $\mathrm{Cu}_{2} \mathrm{O}$; AuNPs, gold nanoparticles; dsDNA, double-stranded DNA; MVC-MOF, mixed-valence state cerium-based metal-organic framework; TMB, 3,3' $5,5^{\prime}$-tetramethylbenzidine; $\mathrm{HCR}$, hybridization chain reaction; $\mathrm{pg}-\mathrm{C}_{3} \mathrm{~N}_{4}$, protonated graphitic carbon nitride; $\mathrm{G}$, guanine; $\mathrm{CNTs}$, carbon nanotubes; ABTS, 2,2'-azino-bis (3-ethyl benzothiazoline-6-sulfonic acid); LOD, limit of detection; LOQ, limit of quantitation; GO, graphene oxide; OTA, ochratoxin A; THMS, triple-helix molecular switch; LAMP, loop-mediated isothermal amplification; PEG, polyethylene glycol; CS1, 
complementary strand 1 of aptamer; CS2, complementary strand 2 of aptamer; AFM1, aflatoxin M1; BNQDs, boron nitride quantum dots; AFB1, aflatoxin B1; OPD, o-phenylenediamine; DAP, 2,3-diaminophenazine; hemin-rGO, hemin-functionalized reduced graphene oxide; CTAB, hexadecyltrimethyl ammonium bromide; cDNA, complementary DNA; MB, magnetic bead; Ni-Fe, nickel-iron; LDO, layered double oxide; $\mathrm{CHA}$, catalytic hairpin assembly; Cu-MOF, copper-based MOF; AuNRs, gold nanorods; BSA, bovine serum albumin; ELAA, enzyme-linked aptamer assay; MNP, magnetic nanoparticles; m-SAP, mesoporous $\mathrm{SiO}_{2} / \mathrm{Au}-\mathrm{Pt} ; \mathrm{BR}-\mathrm{CN}$, benzene-ring-doped g- $\mathrm{C}_{3} \mathrm{~N}_{4}$; FTO, fluorine-doped tin oxide; SA, streptavidin; 4-CN, 4-chloro-1-naphthol; 4-CD, benzo-4chlorohexadienone; AuPd@UiO-67, gold-palladium-modified zirconium metal-organic frameworks; Au@HS-rGO, gold-modified thiol graphene; T-DNA, target DNA; E-DNA, extended DNA; GCE, glassy carbon electrode; AuNCs, gold nanoclusters.

\section{References}

1. Han, Y.; Yang, W.; Luo, X.; He, X.; Zhao, H.; Tang, W.; Yue, T.; Li, Z. Carbon dots based ratiometric fluorescent sensing platform for food safety. Crit. Rev. Food Sci. 2020, 62, 244-260. [CrossRef] [PubMed]

2. Gao, L.; Zhuang, J.; Nie, L.; Zhang, J.; Zhang, Y.; Gu, N.; Wang, T.; Feng, J.; Yang, D.; Perrett, S.; et al. Intrinsic peroxidase-like activity of ferromagnetic nanoparticles. Nat. Nanotechnol. 2007, 2, 577-583. [CrossRef] [PubMed]

3. Das, B.; Franco, J.L.; Logan, N.; Balasubramanian, P.; Kim, M.I.; Cao, C. Nanozymes in point-of-care diagnosis: An emerging futuristic approach for biosensing. Nano-Micro Lett. 2021, 13, 193. [CrossRef] [PubMed]

4. Czescik, J.; Zamolo, S.; Darbre, T.; Rigo, R.; Sissi, C.; Pecina, A.; Riccardi, L.; De Vivo, M.; Mancin, F.; Scrimin, P. A gold nanoparticle nanonuclease relying on a Zn(II) mononuclear complex. Angew. Chem. Int. Ed. 2021, 60, 1423-1432. [CrossRef]

5. Nandhakumar, P.; Kim, G.; Park, S.; Kim, S.; Kim, S.; Park, J.K.; Lee, N.S.; Yoon, Y.H.; Yang, H. Metal nanozyme with ester hydrolysis activity in the presence of ammonia-borane and its use in a sensitive immunosensor. Angew. Chem. Int. Ed. 2020, 59, 22419-22422. [CrossRef]

6. Hu, X.; Huang, T.; Liao, H.; Hu, L.; Wang, M. The phosphatase-like activity of zirconium oxide nanoparticles and their application in near-infrared intracellular imaging. J. Mater. Chem. B 2020, 8, 4428-4433. [CrossRef]

7. Li, B.; Chen, D.; Nie, M.; Wang, J.; Li, Y.; Yang, Y. Carbon dots $/ \mathrm{Cu}_{2} \mathrm{O}$ composite with intrinsic high protease-Like activity for hydrolysis of proteins under physiological conditions. Part. Part. Syst. Char. 2018, 35, 1800277. [CrossRef]

8. Zhang, Y.A.; Jin, Y.L.; Cui, H.X.; Yan, X.Y.; Fan, K.L. Nanozyme-based catalytic theranostics. Rsc Adv. 2020, 10, 10-20. [CrossRef]

9. Wang, Q.; Wei, H.; Zhang, Z.; Wang, E.; Dong, S. Nanozyme: An emerging alternative to natural enzyme for biosensing and immunoassay. Trends Anal. Chem. 2018, 105, 218-224. [CrossRef]

10. Yang, W.; Yang, X.; Zhu, L.; Chu, H.; Li, X.; Xu, W. Nanozymes: Activity origin, catalytic mechanism, and biological application. Coordin. Chem. Rev. 2021, 448, 214170. [CrossRef]

11. Wang, W.Z.; Gunasekaran, S. Nanozymes-based biosensors for food quality and safety. Trends Anal. Chem. 2020, 126, 115841. [CrossRef]

12. Wu, J.J.X.; Wang, X.Y.; Wang, Q.; Lou, Z.P.; Li, S.R.; Zhu, Y.Y.; Qin, L.; Wei, H. Nanomaterials with enzyme-like characteristics (nanozymes): Next-generation artificial enzymes (II). Chem. Soc. Rev. 2019, 48, 1004-1076. [CrossRef]

13. Wang, P.; Min, D.; Chen, G.; Li, M.; Tong, L.; Cao, Y. Inorganic Nanozymes: Prospects for Disease Treatments and Detection Applications. Front. Chem. 2021, 9, 773285. [CrossRef]

14. Navyatha, B.; Singh, S.; Nara, S. AuPeroxidase nanozymes promises and applications in biosensing. Biosens. Bioelectron. 2021, 175, 112882. [CrossRef]

15. Ye, M.L.; Zhu, Y.; Lu, Y.; Gan, L.; Zhang, Y.; Zhao, Y.G. Magnetic nanomaterials with unique nanozymes-like characteristics for colorimetric sensors: A review. Talanta 2021, 230, 122299. [CrossRef]

16. Liu, Q.; Zhang, A.; Wang, R.; Zhang, Q.; Cui, D. A review on metal- and metal oxide-based nanozymes: Properties, mechanisms, and applications. Nano-Micro Lett. 2021, 13, 154. [CrossRef]

17. Jin, J.; Li, L.; Zhang, L.; Luan, Z.; Xin, S.; Song, K. Progress in the application of crbon dots-based nanozymes. Front. Chem. 2021, 9, 748044. [CrossRef]

18. Sun, H.; Zhou, Y.; Ren, J.; Qu, X. Carbon nanozymes: Enzymatic properties, catalytic mechanism, and applications. Angew. Chem. Int. Ed. 2018, 57, 9224-9237. [CrossRef]

19. Huang, X.; Zhang, S.; Tang, Y.; Zhang, X.; Bai, Y.; Pang, H. Advances in metal-organic framework-based nanozymes and their applications. Coordin. Chem. Rev. 2021, 449, 214216. [CrossRef]

20. Jin, S.; Wu, C.; Ye, Z.; Ying, Y. Designed inorganic nanomaterials for intrinsic peroxidase mimics: A review. Sens. Actuator B Chem. 2019, 283, 18-34. [CrossRef]

21. Wang, Q.; Liu, S.; Tang, Z. Recent progress in the design of analytical methods based on nanozymes. J. Mater. Chem. B 2021, 9 , 8174-8184. [CrossRef]

22. Wei, $\mathrm{H}$.; Wang, E. $\mathrm{Fe}_{3} \mathrm{O}_{4}$ magnetic nanoparticles as peroxidase mimetics and their applications in $\mathrm{H}_{2} \mathrm{O}_{2}$ and glucose detection. Anal. Chem. 2008, 80, 2250-2254. [CrossRef] [PubMed] 
23. Shen, Y.; Xu, L.; Li, Y. Biosensors for rapid detection of Salmonella in food: A review. Compr. Rev. Food Sci. Food Saf. 2021, 20, 149-197. [CrossRef]

24. Tao, X.; Wang, X.; Liu, B.; Liu, J. Conjugation of antibodies and aptamers on nanozymes for developing biosensors. Biosens. Bioelectron. 2020, 168, 112537. [CrossRef]

25. Yan, M.M.; Chen, G.; She, Y.X.; Ma, J.; Hong, S.H.; Shao, Y.; Abd El-Aty, A.M.; Wang, M.; Wang, S.S.; Wang, J. Sensitive and simple competitive biomimetic nanozyme-linked immunosorbent assay for colorimetric and surface-enhanced raman scattering sensing of triazophos. J. Agric. Food Chem. 2019, 67, 9658-9666. [CrossRef] [PubMed]

26. Majdinasab, M.; Hayat, A.; Marty, J.L. Aptamer-based assays and aptasensors for detection of pathogenic bacteria in food samples. Trends Anal. Chem. 2018, 107, 60-77. [CrossRef]

27. Wang, L.J.; Wang, R.H.; Wei, H.; Li, Y.B. Selection of aptamers against pathogenic bacteria and their diagnostics application. World J. Microb. Biot. 2018, 34, 149. [CrossRef] [PubMed]

28. Dong, Y.Y.; Xu, Y.; Yong, W.; Chu, X.G.; Wang, D.N. Aptamer and its potential applications for food safety. Crit. Rev. Food Sci. 2014, 54, 1548-1561. [CrossRef]

29. Song, S.-H.; Gao, Z.-F.; Guo, X.; Chen, G.-H. Aptamer-based detection methodology studies in food safety. Food Anal. Methods 2019, 12, 966-990. [CrossRef]

30. Wang, X.; Xu, Y.; Cheng, N.; Wang, X.; Huang, K.; Luo, Y. Recent advances in nucleic acid modulation for functional nanozyme. Catalysts 2021, 11, 638. [CrossRef]

31. Huang, L.; Sun, D.-W.; Pu, H.; Wei, Q. Development of nanozymes for food quality and safety detection: Principles and recent applications. Compr. Rev. Food Sci. Food Saf. 2019, 18, 1496-1513. [CrossRef]

32. Zhang, X.; Wu, D.; Zhou, X.; Yu, Y.; Liu, J.; Hu, N.; Wang, H.; Li, G.; Wu, Y. Recent progress in the construction of nanozyme-based biosensors and their applications to food safety assay. Trends Anal. Chem. 2019, 121, 115668. [CrossRef]

33. Chang, Y.; Gao, S.; Liu, M.; Liu, J. Designing signal-on sensors by regulating nanozyme activity. Anal. Methods 2020, 12, 4708-4723. [CrossRef]

34. Sharma, T.K.; Ramanathan, R.; Weerathunge, P.; Mohammadtaheri, M.; Daima, H.K.; Shuklaa, R.; Bansala, V. Aptamer-mediated 'turn-off turn-on' nanozyme activity of gold nanoparticles for kanamycin detection. Chem. Commun. 2014, 50, 15856-15859. [CrossRef]

35. Pautler, R.; Kelly, E.Y.; Huang, P.J.; Cao, J.; Liu, B.; Liu, J. Attaching DNA to nanoceria: Regulating oxidase activity and fluorescence quenching. ACS Appl. Mater. Interfaces 2013, 5, 6820-6825. [CrossRef]

36. Tarokh, A.; Pebdeni, A.B.; Othman, H.O.; Salehnia, F.; Hosseini, M. Sensitive colorimetric aptasensor based on g- $\mathrm{C}_{3} \mathrm{~N}_{4} @ \mathrm{Cu}_{2} \mathrm{O}$ composites for detection of Salmonella typhimurium in food and water. Microchim. Acta 2021, 188, 87. [CrossRef]

37. Liu, S.; Yang, M.; Guo, W. Programmable and reversible regulation of catalytichemin@MOFs activities with DNA structures Chem. Res. Chin. Univ. 2020, 36, 301-306. [CrossRef]

38. Weerathunge, P.; Ramanathan, R.; Torok, V.A.; Hodgson, K.; Xu, Y.; Goodacre, R.; Behera, B.K.; Bansal, V. Ultrasensitive colorimetric detection of murine norovirus using nanozyme aptasensor. Anal. Chem. 2019, 91, 3270-3276. [CrossRef]

39. Huang, L.J.; Chen, K.; Zhang, W.T.; Zhu, W.X.; Liu, X.N.; Wang, J.; Wang, R.; Hu, N.; Suo, Y.R.; Wang, J.L. ssDNA-tailorable oxidase-mimicking activity of spinel $\mathrm{MnCo}_{2} \mathrm{O}_{4}$ for sensitive biomolecular detection in food sample. Sens. Actuator B Chem. 2018, 269, 79-87. [CrossRef]

40. Wang, J.; Wang, J.; Zhou, P.; Tao, H.; Wang, X.; Wu, Y. Oligonucleotide-induced regulation of the oxidase-mimicking activity of octahedral $\mathrm{Mn}_{3} \mathrm{O}_{4}$ nanoparticles for colorimetric detection of heavy metals. Microchim. Acta 2020, 187, 99. [CrossRef]

41. Wang, C.; Tang, G.; Tan, H. Colorimetric determination of mercury(II) via the inhibition by ssDNA of the oxidase-like activity of a mixed valence state cerium-based metal-organic framework. Microchim. Acta 2018, 185, 475. [CrossRef] [PubMed]

42. Wang, G.; Song, C.; Kong, D.; Ruan, W.; Chang, Z.; Li, Y. Two luminescent metal-organic frameworks for the sensing of nitroaromatic explosives and DNA strands. J. Mater. Chem. A 2014, 2, 2213-2220. [CrossRef]

43. Wang, L.; Liao, T.; Zhou, H.; Huang, Y.; Chen, P.; Yang, X.; Chen, X. Colorimetric method for Salmonella spp. detection based on peroxidase-like activity of $\mathrm{Cu}(\mathrm{II})$-rGO nanoparticles and PCR. Anal. Biochem. 2021, 615, 114068. [CrossRef]

44. Kim, M.I.; Park, K.S.; Park, H.G. Ultrafast colorimetric detection of nucleic acids based on the inhibition of the oxidase activity of cerium oxide nanoparticles. Chem. Commun. 2014, 50, 9577-9580. [CrossRef] [PubMed]

45. Liu, B.; Liu, J. Accelerating peroxidase mimicking nanozymes using DNA. Nanoscale 2015, 7, 13831-13835. [CrossRef] [PubMed]

46. Song, C.; Ding, W.; Liu, H.; Zhao, W.; Yao, Y.; Yao, C. Label-free colorimetric detection of deoxyribonuclease I activity based on the DNA-enhanced peroxidase-like activity of MIL-53(Fe). New J. Chem. 2019, 43, 12776-12784. [CrossRef]

47. Lopez, A.; Zhang, Y.; Liu, J. Tuning DNA adsorption affinity and density on metal oxide and phosphate for improved arsenate detection. J. Coll. Interfaces Sci. 2017, 493, 249-256. [CrossRef] [PubMed]

48. Koo, K.M.; Sina, A.A.I.; Carrascosa, L.G.; Shiddiky, M.J.A.; Trau, M. DNA-bare gold affinity interactions: Mechanism and applications in biosensing. Anal. Methods 2015, 7, 7042-7054. [CrossRef]

49. Liu, M.; Zhao, H.; Chen, S.; Yu, H.; Quan, X. Interface engineering catalytic graphene for smart colorimetric biosensing. ACS Nano 2012, 6, 3142-3151. [CrossRef]

50. Wang, L.; Zhu, F.; Liao, S.; Chen, M.; Zhu, Y.Q.; Liu, Q.; Chen, X. Single-stranded DNA modified protonated graphitic carbon nitride nanosheets: A versatile ratiometric fluorescence platform for multiplex detection of various targets. Talanta 2019, 197, 422-430. [CrossRef] 
51. Zhao, L.; Wang, J.; Su, D.; Zhang, Y.; Lu, H.; Yan, X.; Bai, J.; Gao, Y.; Lu, G. The DNA controllable peroxidase mimetic activity of $\mathrm{MoS}_{2}$ nanosheets for constructing robust colorimetric biosensor. Nanoscale 2020, 12, 19420-19428. [CrossRef] [PubMed]

52. Sun, S.H.; Fan, Y.F.; Du, J.Y.; Song, Z.L.; Zhao, H.M. CNT-modified MIL-88 ( $\left.\mathrm{NH}_{2}\right)$-Fe for enhancing DNA-regulated peroxidase-like activity. J. Anal. Test. 2019, 3, 238-245. [CrossRef]

53. Zeng, C.; Lu, N.; Wen, Y.; Liu, G.; Zhang, R.; Zhang, J.; Wang, F.; Liu, X.; Li, Q.; Tang, Z.; et al. Engineering nanozymes using DNA for catalytic regulation. ACS Appl. Mater. Inter. 2019, 11, 1790-1799. [CrossRef]

54. Zhang, L.; Qi, Z.; Zou, Y.; Zhang, J.; Xia, W.; Zhang, R.; He, Z.; Cai, X.; Lin, Y.; Duan, S.; et al. Engineering DNA-nanozyme interfaces for rapid detection of dental bacteria. ACS Appl. Mater. Inter. 2019, 11, 30640-30647. [CrossRef] [PubMed]

55. Wang, Y.; Liu, J.; Adkins, G.B.; Shen, W.; Trinh, M.P.; Duan, L.; Jiang, J.; Zhong, W. Enhancement of the intrinsic peroxidase-like activity of graphitic carbon nitride nanosheets by ssDNAs and its application for detection of exosomes. Anal. Chem. 2017, 89, 12327-12333. [CrossRef]

56. Zhu, X.; Tang, L.; Wang, J.; Peng, B.; Ouyang, X.; Tan, J.; Yu, J.; Feng, H.; Tang, J. Enhanced peroxidase-like activity of boron nitride quantum dots anchored porous $\mathrm{CeO}_{2}$ nanorods by aptamer for highly sensitive colorimetric detection of kanamycin. Sens. Actuator B Chem. 2021, 330, 129318. [CrossRef]

57. Tang, Y.; Hu, Y.; Zhou, P.; Wang, C.; Tao, H.; Wu, Y. Colorimetric detection of kanamycin residue in foods based on the aptamerenhanced peroxidase-mimicking activity of layered $\mathrm{WS}_{2}$ nanosheets. J. Agric. Food Chem. 2021, 69, 2884-2893. [CrossRef] [PubMed]

58. Hizir, M.S.; Top, M.; Balcioglu, M.; Rana, M.; Robertson, N.M.; Shen, F.; Sheng, J.; Yigit, M.V. Multiplexed activity of perAuxidase: DNA-capped AuNPs act as adjustable peroxidase. Anal. Chem. 2016, 88, 600-605. [CrossRef]

59. Drozd, M.; Pietrzak, M.; Parzuchowski, P.G.; Malinowska, E. Pitfalls and capabilities of various hydrogen donors in evaluation of peroxidase-like activity of gold nanoparticles. Anal. Bioanal. Chem. 2016, 408, 8505-8513. [CrossRef]

60. Zhao, Y.; Li, H.; Lopez, A.; Su, H.; Liu, J. Promotion and inhibition of the oxidase-mimicking activity of nanoceria by phosphate, polyphosphate and DNA. ChemBioChem 2020, 21, 2178-2186. [CrossRef]

61. Zhang, F.; Wang, S.; Liu, J. Gold nanoparticles adsorb DNA and aptamer probes too strongly, and a comparison with graphene oxide for biosensing. Anal. Chem. 2019, 91, 14743-14750. [CrossRef]

62. Park, J.Y.; Jeong, H.Y.; Kim, M.I.; Park, T.J. Colorimetric detection system for Salmonella Typhimurium based on peroxidase-like activity of magnetic nanoparticles with DNA aptamers. J. Nanomater. 2015, 2015, 527126. [CrossRef]

63. Dehghani, Z.; Hosseini, M.; Mohammadnejad, J.; Bakhshi, B.; Rezayan, A.H. Colorimetric aptasensor for Campylobacter jejuni cells by exploiting the peroxidase-like activity of Au@Pd nanoparticles. Microchim. Acta 2018, 185, 448. [CrossRef]

64. Sun, S.; Zhao, R.; Feng, S.; Xie, Y. Colorimetric zearalenone assay based on the use of an aptamer and of gold nanoparticles with peroxidase-like activity. Microchim. Acta 2018, 185, 535. [CrossRef]

65. Yan, J.; Huang, Y.; Zhang, C.; Fang, Z.; Bai, W.; Yan, M.; Zhu, C.; Chen, A. Aptamer based photometric assay for the antibiotic sulfadimethoxine based on the inhibition and reactivation of the peroxidase-like activity of gold nanoparticles. Microchim. Acta 2016, 184, 59-63. [CrossRef]

66. Weerathunge, P.; Behera, B.K.; Zihara, S.; Singh, M.; Prasad, S.N.; Hashmi, S.; Mariathomas, P.R.D.; Bansal, V.; Ramanathan, R. Dynamic interactions between peroxidase-mimic silver NanoZymes and chlorpyrifos-specific aptamers enable highly-specific pesticide sensing in river water. Anal. Chim. Acta 2019, 1083, 157-165. [CrossRef]

67. Li, J.; Yu, C.; Wu, Y.N.; Zhu, Y.; Xu, J.; Wang, Y.; Wang, H.; Guo, M.; Li, F. Novel sensing platform based on gold nanoparticleaptamer and Fe-metal-organic framework for multiple antibiotic detection and signal amplification. Environ. Int. 2019, 125, 135-141. [CrossRef]

68. Weerathunge, P.; Ramanathan, R.; Shukla, R.; Sharma, T.K.; Bansal, V. Aptamer-controlled reversible inhibition of gold nanozyme activity for pesticide sensing. Anal. Chem. 2014, 86, 11937-11941. [CrossRef]

69. Kim, Y.S.; Jurng, J. A simple colorimetric assay for the detection of metal ions based on the peroxidase-like activity of magnetic nanoparticles. Sens. Actuator B Chem. 2013, 176, 253-257. [CrossRef]

70. Yuan, F.; Zhao, H.; Wang, X.; Quan, X. Determination of oxytetracycline by a graphene-gold nanoparticle-based colorimetric aptamer sensor. Anal. Lett. 2017, 50, 544-553. [CrossRef]

71. Zhao, J.; Wu, Y.; Tao, H.; Chen, H.; Yang, W.; Qiu, S. Colorimetric detection of streptomycin in milk based on peroxidase-mimicking catalytic activity of gold nanoparticles. RSC Adv. 2017, 7, 38471-38478. [CrossRef]

72. Yang, W.; Wu, Y.; Tao, H.; Zhao, J.; Chen, H.; Qiu, S. Ultrasensitive and selective colorimetric detection of acetamiprid pesticide based on the enhanced peroxidase-like activity of gold nanoparticles. Anal. Methods 2017, 9, 5484-5493. [CrossRef]

73. Qi, Y.; He, J.; Xiu, F.-R.; Yu, X.; Gao, X.; Li, Y.; Lu, Y.; Song, Z. A convenient chemiluminescence detection for bisphenol A in E-waste dismantling site based on surface charge change of cationic gold nanoparticles. Microchem. J 2019, 147, 789-796. [CrossRef]

74. Qi, Y.; Xiu, F.-R.; Zheng, M.; Li, B. A simple and rapid chemiluminescence aptasensor for acetamiprid in contaminated samples: Sensitivity, selectivity and mechanism. Biosens. Bioelectron. 2016, 83, 243-249. [CrossRef]

75. Xiu, F.R.; Lu, Y.W.; Qi, Y.Y.; Wang, Y.; He, J.H. Ultrasensitive and practical chemiluminescence sensing pesticide residue acetamiprid in agricultural products and environment: Combination of synergistically coupled co-amplifying signal and smart interface engineering. Talanta 2021, 235, 122811. [CrossRef] 
76. Zhu, S.J.; Tang, Y.; Shi, B.; Zou, W.Y.; Wang, X.L.; Wang, C.X.; Wu, Y.G. Oligonucleotide-mediated the oxidase-mimicking activity of $\mathrm{Mn}_{3} \mathrm{O}_{4}$ nanoparticles as a novel colorimetric aptasensor for ultrasensitive and selective detection of Staphylococcus aureus in food. Sens. Actuator B Chem. 2021, 349, 130809. [CrossRef]

77. Das, R.; Dhiman, A.; Kapil, A.; Bansal, V.; Sharma, T.K. Aptamer-mediated colorimetric and electrochemical detection of Pseudomonas aeruginosa utilizing peroxidase-mimic activity of gold NanoZyme. Anal. Bioanal. Chem. 2019, 411, 1229-1238. [CrossRef]

78. Das, R.; Chaterjee, B.; Kapil, A.; Sharma, T.K. Aptamer-NanoZyme mediated sensing platform for the rapid detection of Escherichia coli in fruit juice. Sens. Bio-Sens. Res. 2020, 27, 100313. [CrossRef]

79. Wang, C.S.; Liu, C.; Luo, J.B.; Tian, Y.P.; Zhou, N.D. Direct electrochemical detection of kanamycin based on peroxidase-like activity of gold nanoparticles. Anal. Chim. Acta 2016, 936, 75-82. [CrossRef]

80. Taghdisi, S.M.; Danesh, N.M.; Lavaee, P.; Emrani, A.S.; Ramezani, M.; Abnous, K. A novel colorimetric triple-helix molecular switch aptasensor based on peroxidase-like activity of gold nanoparticles for ultrasensitive detection of lead (II). RSC Adv. 2015, 5, 43508-43514. [CrossRef]

81. Dehghani, Z.; Nguyen, T.; Golabi, M.; Hosseini, M.; Rezayan, A.H.; Mohammadnejad, J.; Wolff, A.; Vinayaka, A.C. Magnetic beads modified with $\mathrm{Pt} / \mathrm{Pd}$ nanoparticle and aptamer as a catalytic nano-bioprobe in combination with loop mediated isothermal amplification for the on-site detection of Salmonella typhimurium in food and fecal samples. Food Control 2021, 121, 107664 [CrossRef]

82. Lavaee, P.; Danesh, N.M.; Ramezani, M.; Abnous, K.; Taghdisi, S.M. Colorimetric aptamer based assay for the determination of fluoroquinolones by triggering the reduction-catalyzing activity of gold nanoparticles. Microchim. Acta 2017, 184, 2039-2045 [CrossRef]

83. Taghdisi, S.M.; Danesh, N.M.; Ramezani, M.; Emrani, A.S.; Abnous, K. Novel colorimetric aptasensor for zearalenone detection based on nontarget-induced aptamer walker, gold nanoparticles, and exonuclease-assisted recycling amplification. ACS Appl. Mater. Interfaces 2018, 10, 12504-12509. [CrossRef]

84. Abnous, K.; Danesh, N.M.; Ramezani, M.; Alibolandi, M.; Nameghi, M.A.; Zavvar, T.S.; Taghdisi, S.M. A novel colorimetric aptasensor for ultrasensitive detection of aflatoxin M-1 based on the combination of CRISPR-Cas12a, rolling circle amplification and catalytic activity of gold nanoparticles. Anal. Chim. Acta 2021, 1165, 338549. [CrossRef]

85. Zhang, Z.; Tian, Y.; Huang, P.; Wu, F. Using target-specific aptamers to enhance the peroxidase-like activity of gold nanoclusters for colorimetric detection of tetracycline antibiotics. Talanta 2020, 208, 120342. [CrossRef]

86. Tan, B.; Zhao, H.; Wu, W.; Liu, X.; Zhang, Y.; Quan, X. $\mathrm{Fe}_{3} \mathrm{O}_{4}$-AuNPs anchored 2D metal-organic framework nanosheets with DNA regulated switchable peroxidase-like activity. Nanoscale 2017, 9, 18699-18710. [CrossRef]

87. Hu, C.; Xi, Q.; Ge, J.; Luo, F.; Tang, L.; Jiang, J.; Yu, R. Graphene-hemin hybrid nanosheets as a label-free colorimetric platform for DNA and small molecule assays. RSC Adv. 2014, 4, 64252-64257. [CrossRef]

88. Hu, J.; Ni, P.; Dai, H.; Sun, Y.; Wang, Y.; Jiang, S.; Li, Z. Aptamer-based colorimetric biosensing of abrin using catalytic gold nanoparticles. Analyst 2015, 140, 3581-3586. [CrossRef]

89. Wang, J.; Zhao, C.; Hong, C.; Lin, Z.; Huang, Z. Rapid detection of malachite green in fish and water based on the peroxidase-like activity of $\mathrm{Fe}_{3} \mathrm{O}_{4} \mathrm{NPs}$ enhanced with aptamer. J. Food Compos. Anal. 2021, 104, 104162. [CrossRef]

90. Bahadoran, A.; Jabarabadi, M.K.; Mahmood, Z.H.; Bokov, D.; Janani, B.J.; Fakhri, A. Quick and sensitive colorimetric detection of amino acid with functionalized-silver copper nanoparticles in the presence of cross linker. Spectrochim. Acta A 2021, $268,120636$. [CrossRef]

91. Yang, Z.; Qian, J.; Yang, X.; Jiang, D.; Du, X.; Wang, K.; Mao, H.; Wang, K. A facile label-free colorimetric aptasensor for acetamiprid based on the peroxidase-like activity of hemin-functionalized reduced graphene oxide. Biosens. Bioelectron. 2015, 65 39-46. [CrossRef] [PubMed]

92. Xiong, Z.; Zhong, H.; Zheng, S.; Deng, P.; Li, N.; Yun, W.; Yang, L. A visual detection of bisphenol A based on peroxidase-like activity of hemin-graphene composites and aptamer. Anal. Methods 2018, 10, 2450-2455. [CrossRef]

93. Chen, X.; Zhai, N.; Snyder, J.H.; Chen, Q.S.; Liu, P.P.; Jin, L.F.; Zheng, Q.X.; Lin, F.C.; Hu, J.M.; Zhou, H.N. Colorimetric detection of $\mathrm{Hg}^{2+}$ and $\mathrm{Pb}^{2+}$ based on peroxidase-like activity of graphene oxide-gold nanohybrids. Anal. Methods 2015, 7, 1951-1957. [CrossRef]

94. Zhao, C.; Hong, C.; Lin, Z.; Chen, X.; Huang, Z. Detection of Malachite Green using a colorimetric aptasensor based on the inhibition of the peroxidase-like activity of gold nanoparticles by cetyltrimethylammonium ions. Microchim. Acta 2019, 186, 322 [CrossRef] [PubMed]

95. Li, L.; Zhao, Y.; Yan, X.; Qi, X.; Wang, L.; Ma, R.; Wang, S.; Mao, X. Development of a terminal-fixed aptamer and a label-free colorimetric aptasensor for highly sensitive detection of saxitoxin. Sens. Actuator B Chem. 2021, 344, 130320. [CrossRef]

96. Zhao, Y.; Li, L.; Ma, R.; Wang, L.; Yan, X.; Qi, X.; Wang, S.; Mao, X. A competitive colorimetric aptasensor transduced by hybridization chain reaction-facilitated catalysis of AuNPs nanozyme for highly sensitive detection of saxitoxin. Anal. Chim. Acta 2021, 1173, 338710. [CrossRef]

97. Yao, Y.; Chen, T.Y.; Mao, W.; Zhong, Y.; Dai, S.S.; Zeng, X.M.; Liu, C.; Tang, S.; Qiao, F.; Shi, E.; et al. Three-dimensional DNA/NiFe layered double oxide frame networks-induced "cusp-exposure" of Au@Ag nanostars for ultrasensitive determination of kanamycin. Sens. Actuator B Chem. 2021, 343, 130082. [CrossRef] 
98. Wu, S.; Duan, N.; Qiu, Y.; Li, J.; Wang, Z. Colorimetric aptasensor for the detection of Salmonella enterica serovar Typhimurium using $\mathrm{ZnFe}_{2} \mathrm{O}_{4}$-reduced graphene oxide nanostructures as an effective peroxidase mimetics. Int. J. Food Microbiol. 2017, 261, 42-48. [CrossRef]

99. Duan, N.; Yang, W.; Wu, S.; Zou, Y.; Wang, Z. A visual and sensitive detection of Escherichia coli based on aptamer and peroxidase-like mimics of copper-metal organic framework nanoparticles. Food Anal. Method. 2020, 13, 1433-1441. [CrossRef]

100. Zhang, L.; Huang, R.; Liu, W.; Liu, H.; Zhou, X.; Xing, D. Rapid and visual detection of Listeria monocytogenes based on nanoparticle cluster catalyzed signal amplification. Biosens. Bioelectron. 2016, 86, 1-7. [CrossRef]

101. Liu, Y.; Wang, J.; Song, X.; Xu, K.; Chen, H.; Zhao, C.; Li, J. Colorimetric immunoassay for Listeria monocytogenes by using core gold nanoparticles, silver nanoclusters as oxidase mimetics, and aptamer-conjugated magnetic nanoparticles. Microchim. Acta 2018, 185, 360. [CrossRef] [PubMed]

102. Liu, Y.; Wang, J.; Zhao, C.; Guo, X.; Song, X.; Zhao, W.; Liu, S.; Xu, K.; Li, J. A multicolorimetric assay for rapid detection of Listeria monocytogenes based on the etching of gold nanorods. Anal. Chim. Acta 2019, 1048, 154-160. [CrossRef] [PubMed]

103. Wang, S.; Deng, W.; Yang, L.; Tan, Y.; Xie, Q.; Yao, S. Copper-based metal-organic framework nanoparticles with peroxidase-like activity for sensitive colorimetric detection of Staphylococcus aureus. ACS Appl. Mater. Inter. 2017, 9, 24440-24445. [CrossRef]

104. Yao, S.; Li, J.; Pang, B.; Wang, X.; Shi, Y.; Song, X.; Xu, K.; Wang, J.; Zhao, C. Colorimetric immunoassay for rapid detection of Staphylococcus aureus based on etching-enhanced peroxidase-like catalytic activity of gold nanoparticles. Microchim. Acta 2020, 187, 504. [CrossRef]

105. Wu, L.; Zhou, M.; Wang, Y.; Liu, J. Nanozyme and aptamer-based immunosorbent assay for aflatoxin B1. J. Hazard. Mater. 2020, 399, 123154. [CrossRef]

106. Tian, F.Y.; Zho, J.; Jiao, B.N.; He, Y. Nanozyme-based cascade colorimetric aptasensor for amplified detection of ochratoxin A. Nanoscale 2019, 11, 9547-9555. [CrossRef]

107. Liu, M.; Yang, Z.; Li, B.; Du, J. Aptamer biorecognition-triggered hairpin switch and nicking enzyme assisted signal amplification for ultrasensitive colorimetric bioassay of kanamycin in milk. Food Chem. 2021, 339, 128059. [CrossRef]

108. Tian, L.; Zhang, Y.; Wang, L.B.; Geng, Q.J.; Liu, D.X.; Duan, L.L.; Wang, Y.H.; Cui, J.S. Ratiometric dual signal-enhancing-based electrochemical biosensor for ultrasensitive kanamycin detection. ACS Appl. Mater. Interfaces 2020, 12, 52713-52720. [CrossRef]

109. Bai, Y.; Wang, Y.; Li, Q.; Dou, L.; Liu, M.; Shao, S.; Zhu, J.; Shen, J.; Wang, Z.; Wen, K.; et al. Binding affinity-guided design of a highly sensitive noncompetitive immunoassay for small molecule detection. Food Chem. 2021, 351, 129270. [CrossRef]

110. Sheng, Y.; Liang, J.; Xie, J. Indirect competitive determination of tetracycline residue in honey using an ultrasensitive goldnanoparticle-linked aptamer assay. Molecules 2020, 25, 2144. [CrossRef]

111. Zhu, X.; Gao, L.; Tang, L.; Peng, B.; Huang, H.; Wang, J.; Yu, J.; Ouyang, X.; Tan, J. Ultrathin PtNi nanozyme based self-powered photoelectrochemical aptasensor for ultrasensitive chloramphenicol detection. Biosens. Bioelectron. 2019, 146, 111756. [CrossRef] [PubMed]

112. Wang, C.; Qian, J.; Wang, K.; Yang, X.; Liu, Q.; Hao, N.; Wang, C.; Dong, X.; Huang, X. Colorimetric aptasensing of ochratoxin A using $\mathrm{Au} @ \mathrm{Fe}_{3} \mathrm{O}_{4}$ nanoparticles as signal indicator and magnetic separator. Biosens. Bioelectron. 2016, 77, 1183-1191. [CrossRef] [PubMed]

113. Qian, J.; Ren, C.C.; Wang, C.Q.; An, K.Q.; Cui, H.N.; Hao, N.; Wang, K. Gold nanoparticles mediated designing of versatile aptasensor for colorimetric/electrochemical dual-channel detection of aflatoxin B1. Biosens. Bioelectron. 2020, 166, 112443. [CrossRef] [PubMed]

114. Tao, Z.; Wei, L.; Wu, S.; Duan, N.; Li, X.; Wang, Z. A colorimetric aptamer-based method for detection of cadmium using the enhanced peroxidase-like activity of Au-MoS 2 nanocomposites. Anal. Biochem. 2020, 608, 113844. [CrossRef]

115. Liu, Q.; He, Z.; Wang, H.; Feng, X.; Han, P. Magnetically controlled colorimetric aptasensor for chlorpyrifos based on copper-based metal-organic framework nanoparticles with peroxidase mimetic property. Microchim. Acta 2020, 187, 524. [CrossRef]

116. Tao, Z.; Zhou, Y.; Duan, N.; Wang, Z. A colorimetric aptamer sensor based on the enhanced peroxidase activity of functionalized graphene $/ \mathrm{Fe}_{3} \mathrm{O}_{4}$-AuNPs for detection of Lead (II) ions. Catalysts 2020, 10, 600. [CrossRef]

117. Wang, Y.; Wang, Y.; Wang, F.; Chi, H.; Zhao, G.; Zhang, Y.; Li, T.; Wei, Q. Electrochemical aptasensor based on gold modified thiol graphene as sensing platform and gold-palladium modified zirconium metal-organic frameworks nanozyme as signal enhancer for ultrasensitive detection of mercury ions. J. Colloid Interf. Sci. 2022, 606, 510-517. [CrossRef]

118. Chen, G.; Jin, M.; Yan, M.; Cui, X.; Wang, Y.; Zheng, W.; Qin, G.; Zhang, Y.; Li, M.; Liao, Y.; et al. Colorimetric bio-barcode immunoassay for parathion based on amplification by using platinum nanoparticles acting as a nanozyme. Microchim. Acta 2019, 186, 339. [CrossRef]

119. Zhang, H.; Yao, S.; Song, X.; Xu, K.; Wang, J.; Li, J.; Zhao, C.; Jin, M. One-step colorimetric detection of Staphylococcus aureus based on target-induced shielding against the peroxidase mimicking activity of aptamer-functionalized gold-coated iron oxide nanocomposites. Talanta 2021, 232, 122448. [CrossRef]

120. Chen, Q.; Gao, R.; Jia, L. Enhancement of the peroxidase-like activity of aptamers modified gold nanoclusters by bacteria for colorimetric detection of Salmonella typhimurium. Talanta 2021, 221, 121476. [CrossRef]

121. Wu, L.; Zhou, S.; Wang, G.; Yun, Y.; Liu, G.; Zhang, W. Nanozyme applications: A glimpse of insight in food safety. Front. Bioeng. Biotechnol. 2021, 9, 727886. [CrossRef] [PubMed] 